\title{
Giorgio Vasari’s Fine Arts From the Vite of 1550: The Splendor of Creativity and Design*
}

\author{
Liana De Girolami Cheney \\ SIELAE, Universidad de Coruña, Spain
}

\begin{abstract}
Giorgio Vasari's conception of artistic creativity is related to his theory of painting. He proposes two alternatives in a painter's development or achievement of artistic creativity: imitation (imitazione) and invention (invenzione). Imitation is the copying of art as a method of learning, whereas invention is independent of imitation and constitutes the means for conceiving artistic ideas. Imitation serves to guide and teach the artist in composing and creating perfection. Vasari maintains that artists must study antiquity and the masters, so that they may learn how others acquired the experience of imitating nature. For Vasari, imitation draws upon three different sources: the first two are copying from nature (copia dal vero) and the third one is selecting from one's work (imitare se stessi). He emphasizes that copying from nature is important for the artist so that he may learn to create forms that are alive as visualized in the Fine Arts.
\end{abstract}

Keywords: beauty, creativity, drawing, imitation, invention, Fine Arts, Giorgio Vasari, Marsilio Ficino, Neoplatonism, Renaissance and Italian Mannerism

\section{Introduction}

It is permissible for the brush to treat philosophical subjects as narrative, since poetry and painting, as sisters, use the same means. (Giorgio Vasari, I Ragionamenti (1574-1588))

In the sixteenth century, artists consulted allegorical, emblematic and mythological texts as sources for their visual conceits. ${ }^{1}$ With a moral overtone, these manuals contain verbal and visual representations of

\footnotetext{
${ }^{*}$ Acknowledgements: A version of this essay was presented at the International Conference on Iconology: Neoplatonism and Art in the Renaissance-Perspectives and Contexts of a (Controversial) Alliance at University of Vienna in Fall 2011, organized by Profs. Sergius Kodera and Berhold Hub of the University of Vienna. I am grateful to both of them for their thoughtful considerations at the conference and insightful comments on this essay. The suggestions of Profs. Aphrodite D. Alexandrakis of Barry University and John Hendrix of Roger Williams University were sincerely appreciated. Another aspect and shorter version about Giorgio Vasari's theory of art was published as Liana De Girolami Cheney, "Giorgio Vasari's Fine Arts: Neoplatonic Visualization of Invention, Imitation and Beauty,” in Luiz Marquez (Ed.), Figura. Studi sull'immagine nella tradizione classica (2012), retrieved from http://figura.art.br/revista.

Liana De Girolami Cheney, Ph.D., Visiting Scholar in Art History, SIELAE, Universidad de Coruña, Spain.

1 The most important of these are Francesco Colonna's Hypnerotomachia Poliphili (Venice: Aldus Manutius, 1499); Horapollo's Hieroglyphica (Venice: Aldus Manutius, 1505); Andrea Alciato’s Emblemata (Basel: Froben edition, 1518/9; and the editions in Augsburg: H. Steyner, 1531;Venice: Aldus Manutius, 1546; and Lyons: Macé Bonhomme for Guillaume Rouille, 1546, 1549 and 1551); Lelio Gregorio Giraldi's De Deis Gentium (Basel: Oporinum, 1548); Natale Conti’s Mythologiae (Venice: Comin da Trino, 1567); Pierio Valeriano's Hieroglyphica (Basel: Palma Ising, 1556); Paolo Giovio's Dialogo dell'Impese Militari et Amorose (Venice: Aldus Manutius, 1556); and Vincenzo Cartari’s Imagini delli Dei degl’Antichi (Venice: Vincenzo Valgrisi, 1556-1557). Cf. Mario Praz, Studies in Seventeenth Century Imagery, 2 vols. (London/Rome: Phaidon, 1941, 1947 and 1964), Introduction; and Jean Seznec, The Survival of the Pagan Gods (New York: Harper and Row Publishers, 1961), pp. 279-327.
} 
virtues, vices, passions and temperaments, revealing a Neoplatonic philosophy. ${ }^{2}$ This essay analyzes how Giorgio Vasari (1511-1574) assimilates Neoplatonism in his artistic concepts of invention, imitation and beauty as depicted in a visual conceit in woodcut of The Fine Arts in the Vite (1550, see Figures 1 and 2). Vasari's artistic idea for the Fine Arts' disegno reveals his art theory.

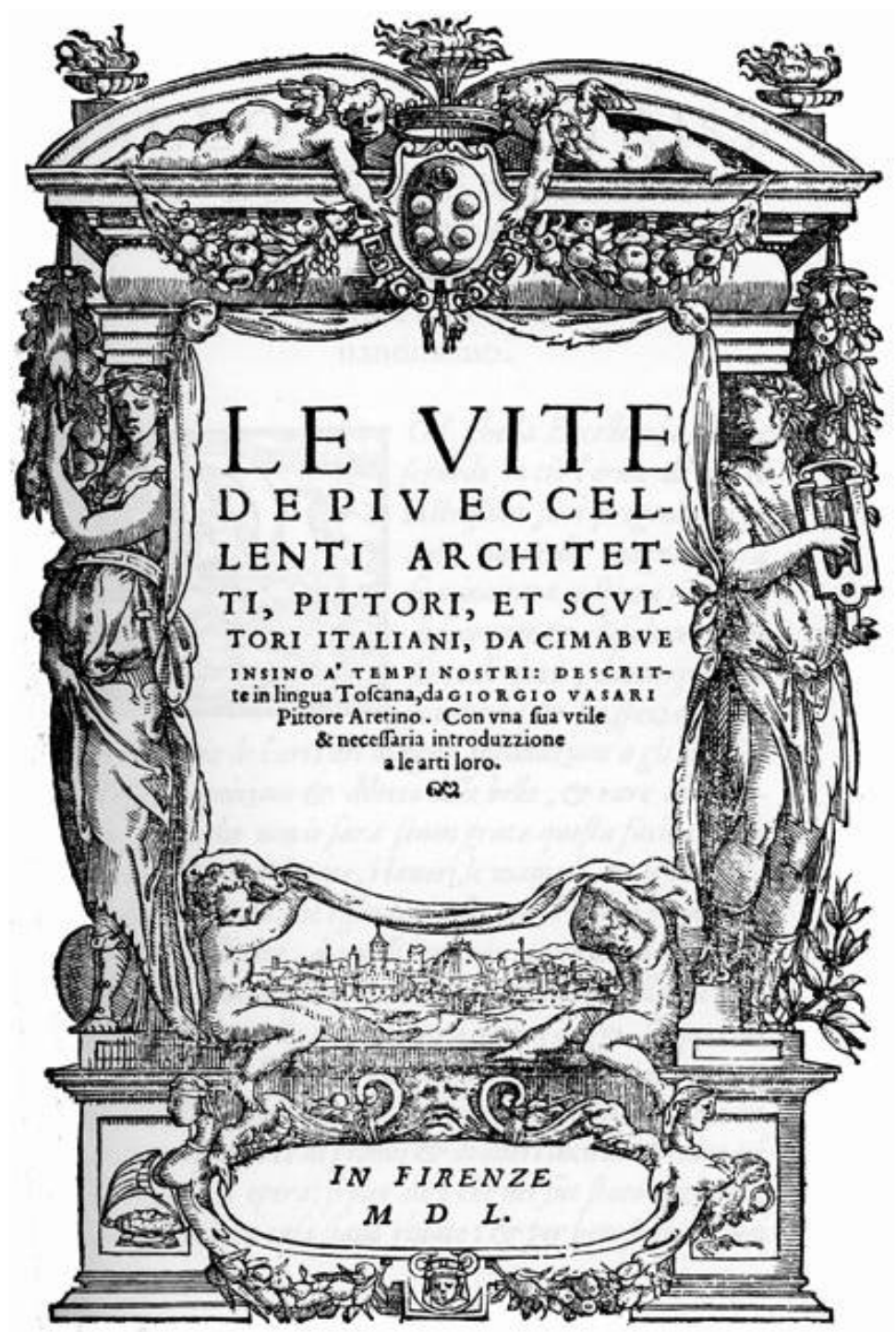

Figure 1. Giorgio Vasari, Frontispiece, 1550, from Le vite de’ piú eccellenti architettori, pittori, e scultori. Lorenzo Torrentino, Florence. (Photo credit: Public Domain, xylography)

Inspired by this humanistic approach, Vasari expresses his artistic intentions, art theory and historical view of art in his writings and in his paintings. In Le vite de' piú eccellenti architettori, pittori, e scultori (original title of the 1550 edition) and Le vite de' piú eccellenti, pittori, scultori et architettori (title of the 1568 edition),

\footnotetext{
${ }^{2}$ Praz, Studies in Seventeenth Century Imagery, II, pp. 5, 36 and 139; George Boas' translation of The Hieroglyphics of Horapollo (New York: Bolligen Series, XXIII, 1950, based on the 1505 version published by Aldus Manutius in Venice); and Daniel Russell, “Alciati’s Emblems in Renaissance France,” Renaissance Quarterly, XXXIV (1981), p. 549. Russell defines the importance of Alciato's book in Cinquecento art and literature: “[It] served as a manual to train readers in a particular approach to artistic artifacts. It taught them to participate actively in the moralizing of visual art, and it showed them how to fragment texts-mainly poetic or dramatic texts; it would appear-into short passages that they could summarize into titular paroemia.”
} 
he expounds his theoretical quest in some length in the prefaces, dedicatory letters and technical manual. ${ }^{3}$ In his artistic practice, he depicts images associated with the Fine Arts (see Figure 2). Here, Vasari reveals his source of creativity, including conceits of invention, imitation and beauty, which in turn are inspired and derived from Marsilio Ficino’s Neoplatonic philosophy.

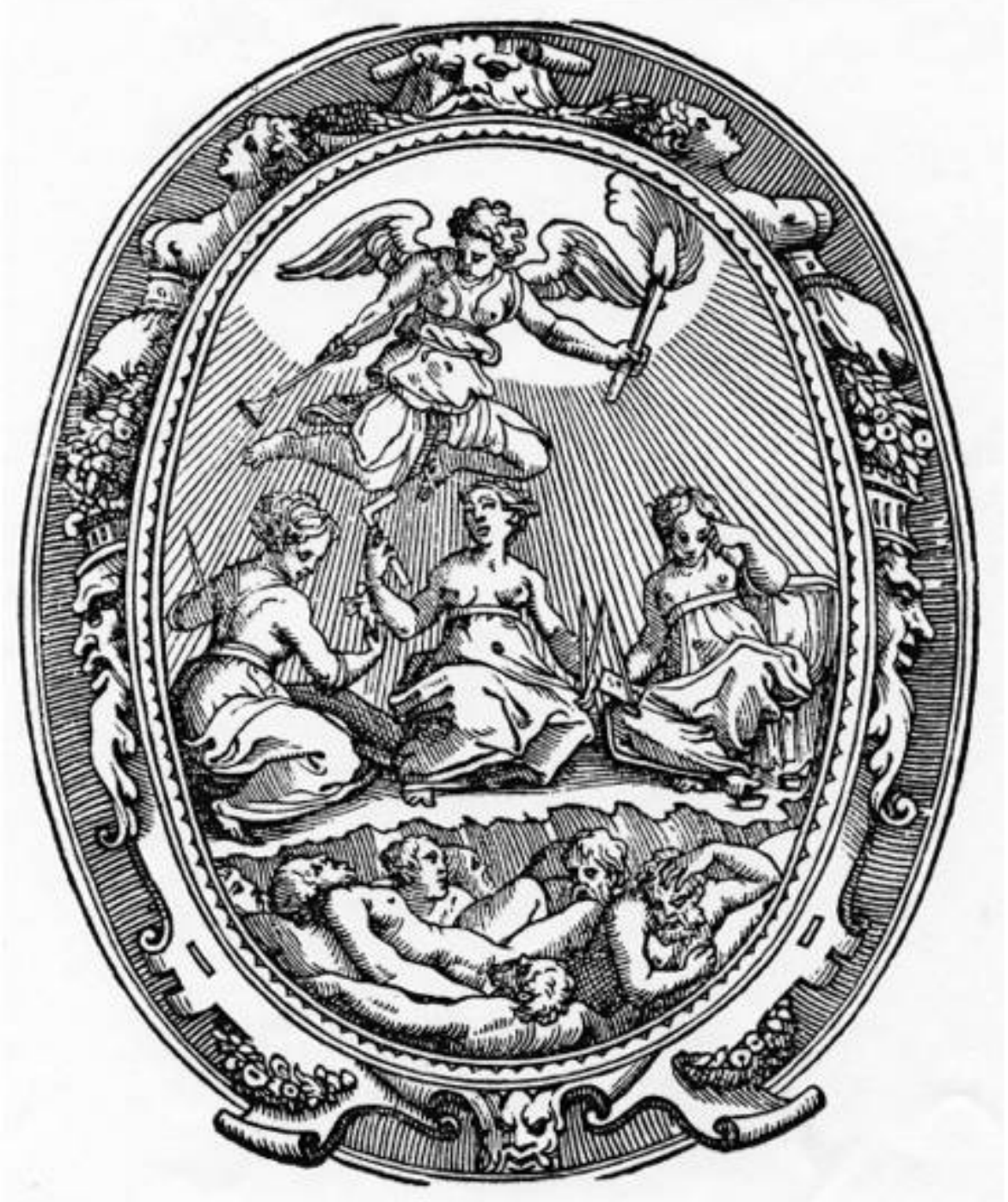

Figure 2. Giorgio Vasari, Endpiece with the Fine Arts, 1550, from Le vite de’ piú eccellenti architettori, pittori, e scultori. Lorenzo Torrentino, Florence (Photo credit: Public Domain, xylography).

Vasari's concept of creativity originates in God, whom he refers to as "Divine Architect of Time and of Nature" in the First Preface of the Vite.

\footnotetext{
3 The title of the 1550 edition is Le vite de' piú eccellenti architetti, pittori, et scultori italiani, da Cimabue insino a' tempi nostri nell'edizione per I tipi di Lorenzo Torrentino Firenze, 1550. This earlier title changes in the 1568 edition of Le vite de' piú eccellenti pittori, scultori e architettori. See the comparative study of Rosanna Bettarini and Paola Barocchi on the 1550 and 1568 editions of Giorgio Vasari, Le vite de’ piú eccellenti architetti, pittori, et scultori (Florence: Sansoni, 1971-1986), vols. I-VI, hereafter referred as Bettarini-Barocchi. For this note, see Bettarini-Barocchi, I, p. xvii.
} 
Cosi, dunque, il primo modello onde uscì la prima imagine dell’uomo fu una massa di terra; e non senza cagione, periciò che il divino Architetto del tempo e della natura, come perfettissimo, volle mostrare nella imperfezzione della materia la via del levare e dell'aggiungere, nel medesimo modo che sogliono fare i buoni scultori e pittori, i quali, ne' lor modelli, aggiungendo e levando riducono le imperfette bozze a quelle fine e perfezzione che vogliono.

(Now the material in which God worked to fashion the first man was a lump of clay, and this was not without reason; for the Divine Architect of time and of nature, being wholly perfect, wanted to show how to create by a process of removing from, and adding to, material that was imperfect in the same way that good sculptors and painters do when, by adding and taking away, they bring their rough models and sketches to the final perfection for which they are striving). ${ }^{4}$

Vasari's view on God as the architect of the universe is based on the Bible and writings of the Middle Ages. For example, in his First Letter to the Corinthians Saint Paul writes:

For we are laborers together with God: ye are God's husbandry, ye are God's building. According to the grace of God, which is given unto me, as a wise master-builder, I have laid the foundation, and another buildeth thereon. But let every man take heed how he buildeth thereupon. For other foundation can no man lay than that is laid, which is Jesus Christ. ${ }^{5}$

Saint Thomas Aquinas (1225-1274), in his Summa Theologica, says, "God, Who is the first principle of things, may be compared to things created as the architect is to things designed" (ut artifex ad artificiata). And in Il Paradiso, Canto 19: 40, Dante Alighieri (1265-1321) praises God The Architect as "Colui che volse il sesto" ("He who turn'd his compass"). ${ }^{6}$ As God is the supreme Creator and Architect, the artist created in the image of God and imitator of God becomes a creator and an architect of the universe, partaking of the natural and divine realms.

As a Renaissance Christian believer and architect by profession, Vasari understands the parallelisms between God and himself. According to Christian credo, he is created in the image of God, and as an architect he is an imitator of God. He visualizes this spiritual relationship (Christian) and practical connection (architect) in his attributed Self-Portrait of 1565 at the Galleria degli Uffizi (see Figure 3). ${ }^{7}$

\footnotetext{
${ }^{4}$ Bettarini-Barocchi, Preface One, II, p. 4.

${ }^{5}$ King James Bible (KJV) (Cambridge, UK: Cambridge University Press as Cambridge Bibles in Baker Publishing Group, 2006), no page, 1 Corinthians 3, 9-11.

${ }^{6}$ Dante, Divine Comedy, Il Paradiso, Allen Mandelboum (Trans. \& Ed.) (New York: Knopf Doubleday, 1995), Canto 19, line 40.

7 The authorship of this self-portrait is questioned. See Alessandro Cecchi, "Giorgio Vasari: Disegnatore e Pittore," in Alessandro Cecchi, Alesssandra Baroni, Liletta Fornasari, Giorgio Vasari, disegnatore e pittore: "studio, diligenza et amorevole fatica." (Milan: SKIRA, 2011), pp. 13-22.
} 


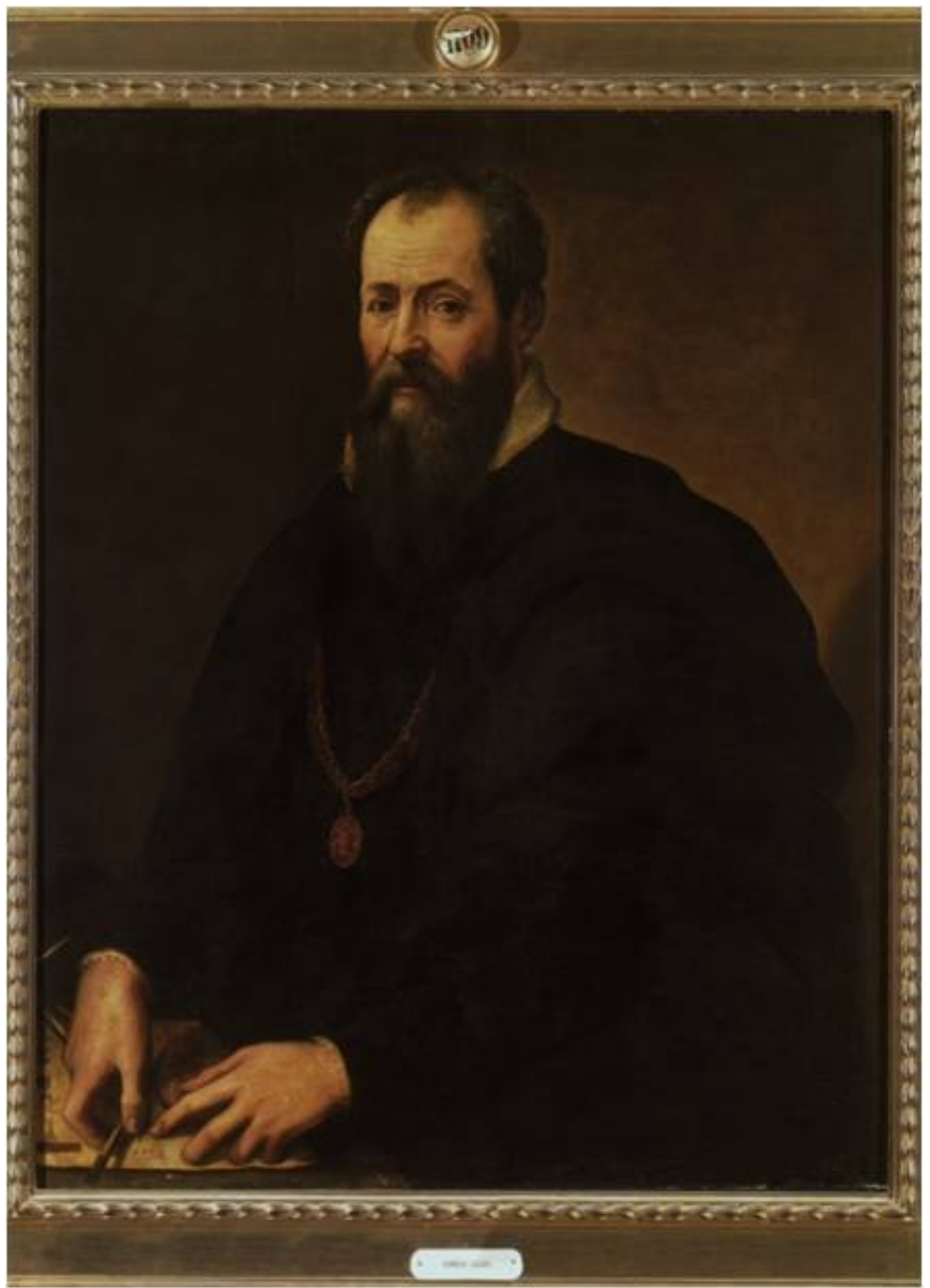

Figure 3. Giorgio Vasari, Self-Portrait, (attributed) 1570, oil on canvass. Galleria degli Uffizi, Florence. (Photo credit: Public Domain)

Here, he depicts himself as an architect, an ambassador of God's creation, standing in front of a table upon which attributes of architecture and drawing instruments are visible. Not by whim, he points to an architectural drawing of his house at Arezzo. Vasari also realizes the importance of the artistic function of architecture as a primary indicator of creativity by placing in the endpiece (a woodcut illustration located at the end of the Vite or facing the last page of the Vite) the personification of Architecture in the center of the Fine Arts (see Figure 2). In the imagery, Fame floats above Architecture, alluding to her dominant artistic role in the Fine Arts. 
Moreover, as indicated in the original title of the Vite, Vasari lists architecture before painting and sculpture. ${ }^{8}$

In the Prefaces to the Vite, Vasari's conception of creativity is further explained and elaborated upon as an historical construct composed of an organic scheme or historical superlative progression. In the second preface, in particular, he defines history as "the true mirror of human life."9 This historical view is interpreted in the Vite in three distinct ways: in the techniques of the arts, the prefaces (proemi) and the biographies (vite). In the techniques of the arts, Vasari explains the methods and materials employed in the making of the three arts of design: architecture, sculpture and painting (The Fine Arts). The prefaces consist of one long preface to the whole oeuvre (proemio di tutta l'opera) and then a trio of prefaces (proemi), where he expounds his philosophy of art and critical theory about the fine arts and gives an overall explanation about the history of art from antiquity to his present time. In the biographies of approximately 162 artists, including his own, he narrates their artistic careers, describing their works as well as their personalities often with amusing anecdotal interjections. The techniques of the arts provide insights into a visual material culture; the prefaces present an almost cyclical view of history, determined by the laws of nature instead of by specific historical events, while the biographies explain the historical process in the evolution of each artist's accomplishments. ${ }^{10}$ Vasari draws a parallel between his intellectual ability to compose the Vite within this framework and God's creation of the world, admitting that it is only possible because God grants the human soul an intellect capable of imitating His design.

L'istessa anima che concepè nutrisce in se medesima tutti i parti degli intelletti-fusse perfettissimo in su l'origine di tutte l'altre cose, quando, l'altissimo Dio, fatto il gran corpo del mondo e ornato il cielo de' sui chiarissimi lumi, discese con l'intelletto più giù nella limpidezza dell'aere e nella solidità della terra, e formando l'uomo, scoperse con la vaga invenzione delle cose la prima forma della scoltura e della pittura.

(The very soul that conceives and nourishes within itself all the parts of the [human's] intellect, was already most perfect before the creation of all other things, when the Almighty God, having made the great body of the world and having adorned the heavens with their dazzling lights, descended with His intellect into the clearness of the air and the solidity of the earth, and, shaping man, discovered, together with the lovely creation of all things, the first form of sculpture and of painting). ${ }^{11}$

The imagery of the endpiece is complex because of Vasari's visual integration of historical, theoretical and moral quests about art. He likens history to the mirror's reflection of human life in this endpiece of $1550 .^{12}$ His purpose in writing the Vite is to provide historical perspective and artistic guidance to his fellow artists. These two significant issues are evident in his explanation of the concept of rebirth, in which he combines the concept of progress with that of moral intention. Vasari's idea of progress is described by means of the changes from imperfection to perfection in the artists' works. And his concept of moral intention is related to the Cinquecento (sixteenth century) notion of the spirit of history, which fulfills its real purpose in helping individuals to be

\footnotetext{
${ }^{8}$ See Liana De Girolami Cheney, “Giorgio Vasari’s Studio, Diligenza ed Amorevole Fatica,” in Reading Vasari, A. Barriualt, et al. (Ed.) (London: Philip Wilson, 2004), pp. 259-277, for a discussion on the original title of the Vite; and Liana De Girolami Cheney, “Giorgio Vasari and Mannerist Architecture: A Marriage of Beauty and Function in Urban Spaces,” Journal of Literature and Art Studies, vol. 6, No. 10 (October 2016), pp. 1150-71.

${ }^{9}$ See Bettarini-Barocchi, Preface Two, III, pp. 3-4.

${ }^{10}$ Liana De Girolami Cheney, Giorgio Vasari’s Prefaces: Art and Theory (London/New York: Peter Lang Publishers, 2012), pp. xxx1-lxxiii.

${ }_{11}^{11}$ See Bettarini-Barocchi, Preface One, II, p. 3.

12 See Bettarini-Barocchi, Preface Two, III, pp. 3-20.
} 
prudent and showing them how to live. ${ }^{13}$

Vasari's historical interpretation emerges from an extended comparison between artistic changes and the life and death of a person in a gradual and superlative progression. He considers three main biological developments in a person's life: childhood, adolescence and maturity or adulthood. He then incorporates this biological scheme when he described the vite of the artists. In the first period (prima maniera), for example, Vasari describes the art of these artists as child-like and rudimentary. In doing so, he praises these artists because they are beginning to learn the rules but thinks them imperfect. In the second period (seconda maniera), Vasari considers these artists to be in an adolescent phase. Like precocious youngsters, they depend on strict rules of art but lack the overall confidence and independence of an adult. In last and third period (terza maniera), Vasari describes these artists as being fully mature adults. In this period they deal easily with technical difficulties, exercise independent certainty of judgment and display an ability to express very complex emotional states. In other words, here art has fulfilled its potentiality. ${ }^{14}$ Thus, in the Vite, the endpiece with the Fine Arts visually encapsulates the aims of the first book of art history in the Cinquecento, where the introduction of techniques of arts, theoretical prefaces and artists' biographies manifest a historical development of artists' creativity.

In the endpiece (see Figure 2), the historical development of these three biological stages or art periods in the Vite is compared with the visual composition of a three-layer motif. The outer layer with a simpler, insipid design can be associated with the stage of childhood; the second layer with the elaborate design and decorative cartouche with the stage of adolescence; and the inner layer where the Fine Arts reside with the stage of adulthood or full realization of a disegno.

The overall circular design of the endpiece alludes to the motif of the wheel, a symbol of the cycle of life (birth and rebirth). ${ }^{15}$ With this imagery, Vasari continues two significations: one divine and the other secular. The divine or celestial allusion is related to its shape, similar to the sun or the solar cosmos, as well as to fiery power of the sun. In pagan mythology, Apollo personifies the Sun God and cosmos, while in Christian religion the sun, the fire and the wheel are associated with God's apocalyptic powers. ${ }^{16}$ The secular signification refers to his historical progression as well as artists' efforts now brought to light, even if time has passed, by the publication of the Vite. ${ }^{17}$ At the bottom of the design, dormant and recumbent figures are awakened by Fame's sonorous trumpet and flaming torch, who is located at the top of the design. These figures represent the deceased artists who have excelled in their artistic careers by "mirroring nature" (imitating nature). In the center of the composition, the symbolic imagery incorporates the depiction of the Fine Arts (Sculpture, Architecture and Painting). The enlivened depiction of the personifications of the Fine Arts signifies that one or

\footnotetext{
${ }^{13}$ See Patricia Rubin, Giorgio Vasari: Art and History (London: Yale University Press, 1995), p. 154, and pp. 152-165.

${ }^{14}$ See Bettarini-Barocchi, Preface Two, III, p. 5.

15 See Simone Bartolini, Sole e Simboli (Florence: Edizione Polistampa, 2013), pp. 47-51; Guy de Tervarent, Attributs et Symboles dans L'Art Profane (Geneva: Droz, 1997), p. 379; and Jean Chevalier and Alain Gheerbrant A Dictionary of Symbols, trans. John Buchanan-Brown (Oxford: Basil Blackwell, Ltd., 1994), pp. 1099, for a discussion on the cycles of life, and 1102, for an association of the wheel with the sun, fire and celestial movements, including Neoplatonic "unrolling divine revelation."

${ }^{16}$ See Jerusalem Bible, Alexander Jones (Ed.) (New York: Doubleday \& Company, 1968), Daniel's vision of the Ancient Days and the Son of Man (7: 9-10): "His throne was a blaze of flames, its wheels were a burning fire," and Ezekiel’s vision of God sending, cherubim in wheels of fire cherubim to purify Israel (Ezekiel 9: 8-9 and 10: 2-3). For Pseudo-Dionysius the Areopagite (5th to 6th century), Christian Neoplatonic theologian, the wheel symbolizes the unveiling of divine revelation. See also, Pseudo Denys l'Aréopagite, Hiérachie céleste (Oeuvres completes), trans. Maurice de Gandillac (Paris: Aubier, 1943), pp. 49-50.

17 With the imagery of resurrected bodies, no doubt Vasari is visually referring to Michelangelo's Last Judgment of 1541-1543, in the Sistine Chapel.
} 
more of the artists' accomplishments are finally recognized by the efforts of Vasari's writings.

Visually, Vasari composes another metaphorical layer of symbolic associations from past and present, commencing with the outer design of the oval (elliptical) frame. This type of design recalls ancient numismatic, an imagery of the past, which becomes a source of inspiration for Renaissance artists. Moving to the second oval frame, the designed cartouche is composed of female herms and crowned mascheroni interlaced with festoons. These figures are engaged in a rotary movement, implying a turning wheel of fortune, the vicissitudes of destiny, where acknowledgement and celebrity of artistic deeds is feasible. With this progression, the last oval frame combines the sublimation of artistic endeavors. The third oval portrays the personifications of the Fine Arts, which are depicted with their respective attributes or the instruments of their art. At the left, Sculpture is holding a chisel and a nude sculptural form; in the center, Architecture is showing a scale and other devices of measurements; and at the right, painting is resting a palette on her lap with painter's containers at her feet.

These elliptical shapes with honorific motifs parallel the trio of the Fine Arts. The most external elliptical shape recalls a classical medallion frame, ${ }^{18}$ the second and central elliptical shape is composed as a cartouche, ${ }^{19}$ and the third inner oval shape alludes to a mirror. ${ }^{20}$ The design of the first elliptical shape, with its repetitious hatching lines, creates a textural surface and provides a three-dimensional illusion for the entire imagery. The second elliptical design is composed of a lush garland intertwined in the frame of the cartouche. Inserted in the garland motif, in an alternating pattern, are depictions of crowned, bearded masks and female herms. The allocation and movement of the imagery not only embellishes this honorific décor but also suggests a rotary movement, similar to the turning of a wheel, perhaps more specifically the rotation of a Wheel of Fortune. ${ }^{21}$ The third elliptical shape contains a portrayal of the personification of the Fine Arts (Sculpture on the left, Architecture in the center and Painting on the right of the disegno). Seated females hold their attributes of labor and reside on a summit.

In the endpiece print, the third oval shape reveals a reverse imagery, which alludes to two types of realms, natural and metaphysical. The natural realm comprises a physical construction of the endpiece in terms of material (woodcut print), decorations (cornucopias), size (format), shape (oval), like an ancient medallion, a commemorative coin or a cartouche. The metaphysical realm is revealed by the allusion that the print has a

\footnotetext{
${ }^{18}$ Vasari's Endpiece may allude to a type of honorific medal, similar to the Renaissance medal of Matteo de' Pasti's Leon Battista Alberti of 1446. See the bronze medal, Number A. 172-1910, at the Victoria and Albert Museum, London, UK.

${ }^{19}$ In the Sala dei Cento Giorni in the Palazzo della Cancelleria in Rome, Vasari depicts several cartouches in the dado. See Liana De Girolami Cheney, “Giorgio Vasari’s Sala dei Cento Giorni: A Farnese Celebration,” Exploration in Renaissance Culture, vol. XXI (1995), pp. 121-151.

${ }^{20}$ Vasari may be referring to a well-known medieval image, the Wheel of Fortune of 1372, in the pavement of the Duomo of Siena. Here, the imagery depicts the king enthroned at the wheel's summit, and three other figures clasping the wheel at opposing points. Four philosophers of antiquity are portrayed in hexagons placed at the four corners of the panel: Epictetus, Aristotle, Euripides and Seneca. Cf. Florian Ebeling, The Secret History of Hermes Trismegistus: Hermeticism from Ancient to Modern Times (New York: Cornell University Press, 2007), Cover page for the illustration. See also Marilena Caciorgna and Roberto Guerrini, Il pavimento del duomo di Siena. L'arte della tarsia marmorea dal XIV al XIX secolo fonti e simologia (Siena: Silvana Editoriale, 2004), for further iconography on the symbolism of the pavement. See Leslie Thomson, "Classical Origins," in Leslie Thomson (Ed.), Fortune: “All is but Fortune” (Washington, DC: University of Washington Press, 2000), pp. 11-20.

${ }^{21}$ Leslie Thomson, "Consolation of Christianity," in Thomson (Ed.), Fortune: “All is but Fortune,” pp. 15-21. Vasari depicts the personification of Fortune and the symbolism of the Wheel of Fortune in the ceiling of the Chamber of Fortune in 1548, in his house at Arezzo. See Liana De Girolami Cheney, The Homes of Giorgio Vasari (London/New York: Peter Lang Publishing, 2006), pp. 135-140, for a discussion of the palco image depicting Fortuna and its association with the Wheel of Fortune, as well as with Niccolò Machiavelli’s concept of Fortune. Cf. Hanna Fenichel Pitkin, Fortune is a Woman: Gender and Politics in the Thought of Niccolò Machiavelli (Chicago: University of Chicago Press, 1984).
} 
different two realms: the first being the reverse image projected by the print itself and the second being an echo of the original disegno for the reversal image.

With the depiction of a reverse imagery in the endpiece, Vasari is, perhaps, visually referring to the Platonic notion of mimesis (imitation). ${ }^{22}$ The natural world or physical existence is a reflection of the ideal world or the essence of life. The realm of reality is a copy or an imitation of the ideal realm. In this line of thinking, metaphorical transformations occur from life to afterlife, from past to present, from oblivion to fame, and from the action of descending (tomb or death) to ascending into the realm of the Fine Arts (a summit). Vasari immortalizes his artistic colleagues in the endpiece by depicting them at the bottom of the composition, awakening and arising at the sound of Fame's trumpets. He furthermore honors them by writing about their lives and presenting the endpiece as the last illustration in the tome. Vasari's imagery alludes to a metaphorical resurrection of the artists and recognition of their artistic accomplishments. Their awakening to the realm of artistic quests is paralleled by the awakening of the audience's (reader and viewer) response in acknowledging and rewarding the creativity and merits of these artists. And the good fortune is that Vasari's art and writings make it possible and grant them fame.

As he designs three levels of elliptical design, Vasari also composes three levels of symbolic transformations. These levels are based on ascending aesthetic criteria. ${ }^{23}$ Viewing the imagery in Renaissance Neoplatonic terms, the lower area or first level, where the figures are recumbent, depicts the natural realm. Above these recumbent figures or on the second level, the Fine Arts resides. This second level represents the intellect or nous. ${ }^{24}$ And at the top of the Fine Arts, Fame abides; this area is the third level, or the celestial or heavenly realm. The Fine Arts residing in the nous realm are depicted discalced and in seated poses as Michelangelesque sibyls, alluding to their abstract identity and personification of artistic forms such as Sculpture, Architecture and Painting. The Fine Arts are also placed in an intermediary position between the celestial realm, where Fame resides, and the natural realm, where the deceased artists repose. Thus, the Fine Arts, in the nous or intellect realm, are a conduit for the recognition of the achievements of the artists. They facilitate the transformation and ascending movement of the artists from the natural realm to the celestial realm.

In the middle of the composition or the intellectual (nous) realm, the Fine Arts cogitate on a mountaintop. Appropriately, this area symbolizes Mount Parnassus or the Mount of Muses where the Fine Arts reside as the Muses in Raphael's Parnassus of 1510, in the Stanza della Segnatura at the Vatican. In antiquity, Mount Parnassus, also called mouseion (museum), was considered a sacred place reserved for the muses and their artistic, intellectual and spiritual interactions. In the Cinquecento, however, following Hesiod's account in the

\footnotetext{
${ }^{22}$ Plato discusses this concept in the Republic, Book III, particularly in Book X. See Stephen Halliwell, Plato Republic 10 (Warminster: Aris and Phillips, 1988), p. 119; and Stephen Halliwell, "Beyond the Mirror of Nature: Plato's Ethics of Visual Forms," in A. E. Denham, Plato on Art and Beauty (New York: Palgrave McMillan, 2012), pp. 173-205.

${ }^{23}$ See Michael J. B. Allen, Marsilio Ficino: Platonic Theology, vol. I (Cambridge, MA: Harvard University Press, 2001), Book V, Chapter 1, pp. 261 and 283, on the movement of ascent and descent of the soul.

${ }^{24}$ This is the Neoplatonic category of the sense of perception for the formation of art, as well as source of reason for the conception of the notions of creativity (invention, imitation and judgment). Vasari's realm of nous may also be related to Leonardo's concept of perception as the "eyes are the window of the soul.” The depiction of the Fine Arts is an abstract artistic creation. See Plotinus, Enneads, A. H. Armstrong (Trans.), Plotinus, vol. 5 (Cambridge, MA: Harvard University Press, Loeb Classical Library, 1984), Enneads V 1-9, for a discussion of nous as part of the intelligence realm in human beings; Richard Rorty, Philosophy and the Mirror of Nature (Princeton: Princeton University Press, 1979), pp. 38-39, for a discussion of nous and perception; and Riccardo Chiaradonna, Plotino (Rome: Carocci, 2012), pp. 70-72, for a discussion on nous associated with the concept of beauty and self-reflection, in particular, p. 71, on the passage in Enneads V 8: 31: "È il concetto di bellezza, che caratterizza la perfezione autoriflessiva del Nous" ("The concept of beauty characterizes the perfection of the self-reflection of Nous").
} 
Theogony, other mountains were sacred to the muses, since they were born at the foot of Mount Olympus or on Mount Helicon in Boetia. ${ }^{25}$ Enthralled by this theme, Vasari depicts the muses in several locations, in particular, in his Aretine house, on the ceiling of the Chamber of Apollo and the Muses of 1550-1554 and in the Palazzo Vecchio, Scrittorio di Calliope of $1558 .^{26}$

Vasari draws a parallel between the actions and significance of the Fine Arts and the power of creativity of the ancient Muses. The Muses reside on Mount Parnassus or Mount Helicon, where they rule over the arts and provide inspiration for the artists. Apollo, the Sun God, taught them the arts and inspired them to create beauty with their imagination. Vasari's Fine Arts assume the role of the Muses. With their respective attributes, they are also placed on a summit. At top, the Fine Arts manifest the creativity of the artists, bathed by the sun and its rays, an allusion of divine light and inspiration, and surrounded by a glowing atmospheric light, a reference to an inspirational fire a furor poeticus or what I would refer as furor artisticus.

In the endpiece, winged Fame touches the sun with her torch in order to obtain and transmit divine light and not only illuminate the presence of the Fine Arts but also awaken the deceased artists and guide them to the summit of human celebrity and divine blessings. Vasari forecasts the ultimate destiny of his fellow artists by prophetically aggrandizing them and elevating them to a zenith of inspiration, creativity and beauty in the realm where the Fine Arts reside. Vasari provides an apocalyptic vision, uniting a historical progression, mythological references and religious symbolism. The historical progression is expounded in the Vite with the evolution of the Fine Arts from the first period to the third period. The pagan mythology is associated with numerous ancient personages and tales that parallel Cinquecento narrative conventions. For example, the Muses as sources of inspiration in the arts influence the portrayal of the Fine Arts; Mount Helicon as the summit of knowledge because the Muses reside on this peak and are guided by Apollo, the Sun God, as well as by their mother, Mnemosyne, the Memory Goddess, thus recalling the Muses’ nature. The Fine Arts can be considered the Muses' counterpart in Cinquecento culture.

The Fine Arts also reside in the summit of the intellect (nous) and are inspired by God's emanation of His grace and light. The Christian religious symbolism is intertwined with the historical and mythological connections. These notions reveal Vasari understanding of Marsilio Ficino's philosophical quest in reconciling paganism and Christianity ${ }^{27}$ and in projecting an artistic path for honoring the artists and eroding the conception of artist as mere craftsmen. Visually and metaphorically, Vasari's recumbent artists, through divine illumination and the resonant sound of glory, will arise from slumber and reach the summit of fame. With this imagery, Vasari probably parallels a Christian judgment and resurrection of beings with Fame's thunderous call and the arising of the artists through their accomplishments in the Fine Arts. The Christian Second coming

\footnotetext{
${ }^{25}$ See Hesiod, Theogony, translated by Dorothea Wender (Baltimore: Penguin Books, 1976), pp. 25-27. See also Liana De Girolami Cheney, "Vasari’s Pictorial Musing on the Muses: The Chamber of Apollo of the Casa Vasari,” Studies in Iconography, vol. 15 (Spring 1994), pp. 135-177; M. Mayer, "Musen,” in Paulys Realencyclopädie der classischen Altertumswissenschaft, Georg Wissowa (Ed.) (Stuggart: J. B. Metzlerscher Verlag, 1933), vol. 16. 1, cols. 680-757; and Ch. Walde, "Musen,” in Der Neue Pauly, Hubert Cancik and Helmuth Schneider (Eds.) (Stuttgart: J. B. Metzler, 1996-2000), vol. 8, pp. 511-514, for a discussion of the Muses as inspirational sources and personifications of the arts. See also M. Mayer, "Helikon-Hestia," in Paulys Realencyclopädie der classischen Altertumswissenschaft, Wilhelm Kroll (Ed.) (Stuggart: J. B. Metzlerscher Verlag, 1912), vol. 15, Bd, VIII. 1, for a discussion of Mount Helicon.

${ }^{26}$ Liana De Girolami, “Giorgio Vasari’s Calliope, Muse of Poetry and Music,” in Liana De Girolami Cheney and John Hendrix (Eds.), Neoplatonism and the Arts (New York/London: Edwin Mellen Press, 2002), pp. 215-226, Chapter 12, Figure 1.

27 See Paul Oskar Kristeller, Renaissance Thought: The Classic, Scholastic and Humanist Strain (New York: Harper \& Brothers, 1961), pp. 58 and 85, and pp. 70-91, on Paganism and Christianity. See also Paul Oskar Kristeller, Renaissance Thought II (New York: Harper and Row Publishers, 1965), p. 91.
} 
promulgated in the Bible ${ }^{28}$ and by the Christian Church fathers-in particular, Saint Thomas Aquinas-is internalized by the devotee Vasari and projected into his imagery (endpiece) and writings, in particular, his Letter to The Artists of Disegno, claims to recognize the accomplishments of all artists: not just of those in the Third Period (terza maniera) but also artists of all periods, from ancient, modern (Vasari’s time) and future generation. Vasari writes:

Accetate dunque con animo grato queste mie fatiche, e qualunque le sieno, da me amorevolmente per gloria dell'arte et onor degli artefici condotte al suo fine, e pigliatele per un indizio e pegno certo dell'animo mio, di niuna altra cosa più desideroso che della grandezza e della gloria vostra; della quale, essendo ancor io ricevuto da voi nella compagnia vostra (di che e voi ringrazio e per mio conto me ne compiaccio non poco), mi parrà sempre in un certo modo partecipare.

(I have anxiously conducted the work to its close, for the glory of art, and to the honor of artists; receive it then as a sure token and pledge, of my heart, which is of nothing more desirous than of your greatness and glory. In the which, I being received by you into your Society [wherefore I am both thankful to you, and rejoiced no little as for mine own part], it appears to me that I always, in a sort, participate). ${ }^{29}$

In Vasari's endpiece, the natural realm with the dormant forms at the bottom of the composition is most intriguing. This level is below the Fine Arts, where Vasari depicts an abysm filled with nude human bodies being awakened by the loud sound of the trumpet and the flaming torch, allusions to a call for the recognition of their artistic accomplishments. Here, Vasari designs seven human figures reacting differently to the sonorous trumpet of Fame. Some are awaking; one figure, in particular, extends his arms to address the entire group while turning his head to specifically view the personification of Sculpture. She glances and honors the figure as a sculptor by raising a nude statue. With these figures' gestures and actions, Vasari helps the viewer connect the personification of Sculpture with a sculptor and related achievements in the art of sculpting. The reclining figure recalls Michelangelo's recumbent figures, such as Christ in the Pieta of 1498 at the Vatican, and the personification of Time on the Medici Tombs of 1524-1533, in the New Sacristy of San Lorenzo. Vasari's Sculpture is a flipped image of Michelangelo's Libyan Sibyl. She is the only member of the Fine Arts who is clothed and turning toward the other two artistic sisters, Architecture and Painting. In this depiction, Vasari is alluding also to the concept of the Renaissance paragone between the superiority of sculpture or painting as an artistic form. ${ }^{30}$ Vasari, for example, appropriates a painted figure (Libyan Sibyl) to symbolize Sculpture, which holds sculptural attributes that symbolize measurement, proportion and rules, which are employed in the art of painting and sculpturing.

Opposite Sculpture, Vasari depicts Painting, whose pose recalls Raphael's portrayal of Michelangelo as the ancient philosopher, Heraclitus, in the Stanza della Segnatura of the papal apartments at the Vatican. The pensive figure of painting, resting her head on her arm, looks down at the dormant figures, in particular, at a figure that parallels her pose and resembles Michelangelo's portrayal of Heraclitus. Painting is surrounded by her attributes of drawing and paint, a brush, a palette and color containers. Here, the artistic paragone continues,

\footnotetext{
${ }^{28}$ See Jerusalem Bible, Ps. 118: 221-223: prophetic insight on the resurrection; Ps. 72: 1-3: "His [Son of Man/God] second coming, when He will judge justice, He will come before the eyes of all”; and I Corinthians 15: 51-53, describing the resurrection of the dead as "the last trumpet." See also Saint Thomas Aquinas, Summa Theologia, Question 73, on The Signs that will precede the Judgment: "For judgment to be passes, the authority of the judge needs to be known: and for this reason it behooves that the coming of Christ unto judgment should be manifest."

${ }^{29}$ See Bettarini-Barocchi, Vasari's Letter to the Artists of Disegno, I, p. 176.

${ }^{30}$ L. Mendelsohn, Paragoni: Benedetto Varchi Due Lezzioni and Cinquecento Art Theory (Ann Arbor: UMI Research Press, 1982), pp. 109-142.
} 
now with the painted figure of a sculptor (perhaps Michelangelo) symbolizing painting. Vasari's paragone among the Fine Arts evolves further: in holding the instrument of their arts, they are personifying human creativity, which can be paralleled with divine creation and divine inspiration, God being The First Creator.

Not by accident, Architecture resides in the center of the group. She is the only personification that does not glance down at the dormant group. Fame floats above her. Vasari portrays Architecture with her corresponding instruments of compass, ruler and other measuring devices, symbolizing order, measurement, proportion and rules. Vasari holds in high esteem the creativity of Architecture and architects, as indicated by the original title of his Lives in 1550, Le vite de' piú eccellenti architettori, pittori, e scultori. He not only associates Architecture with God as First Architect and divine construction of the universe but also considers Architecture to be most necessary to the individual's well being ("necessaria e utile alla salute del corpo") ${ }^{31}$ and cultural preservation. Because of its materiality, structure and function, Architecture is easier to imitate, maintain and restore, and thus survives through time. Vasari says: "Architects in making the new imitate in large part the old" ("architetti nel fare i nouvi imitano in gran parte i vecchi'). ${ }^{32}$ In the personification of Architecture, Vasari is further alluding to a historical continuum, immortalizing artists and their works as well as imputing a divine connection, restating the unity between an architect's creations and God, First Architect, creator of the universe.

Furthermore, in the endpiece, the central placement of the personification of Architecture, holding the attributes of measurement (ruler or square and compass) and seated as an enthroned figure, recalls personifications of Nemesis and Justice. ${ }^{33}$ In this imagery of Architecture, Vasari unites the symbolism of normative Justice (Nemesis) with moral Justice (Giustizia) or giudizio (judgment). He considers judging works of art in terms of their artistic merits such as invention (invenzione), proportion (proportzione) and disegno ${ }^{34}$ as being an example of Nemesis. He considers beauty, goodness and perfection in the creation of art and prudence in an artist's behavior as examples of moral or ethical Justice. ${ }^{35}$ Likely, Vasari is inspired by and considers the impact of divine justice as depicted in Michelangelo's Last Judgment of 1541 in the Sistine Chapel at the Vatican (see Figure 4).

\footnotetext{
31 Bettarini-Barocchi, Preface One, II, p. 17.

32 Bettarini-Barocchi, Preface One, II, p. 15.

33 See de Tervarent, Attributs et Symboles dans L'Art Profane, p. 196: the square is a symbol of Justice as well as Nemesis, which means norm or measurement in Latin. See also Vincenzo Cartari, Imagini delli Dei degl'Antichi (Venice: Evangelista Deuchino \& Gio.Batttista Pulciani, 1556), p. 348, who unites the image of Justice with Nemesis (distributor of Fortune). See Statue of Nemesis dedicated by Ptollanubis, second century CE, Musée du Louvre (Ma4873.jpg), holding similar attributes as Fortune, e.g., compass or wheel. See also the engraving of Albrecht Dürer, Melancholia of 1514, British Museum, London (PD 1912-12-20-2/B.74), with measuring instruments, including a square, a quadrant and a compass.

${ }^{34}$ See Bettarini-Barocchi, III, Masaccio's vita, p. 230: Donatello's vita, p. 225.

35 See Bettarini-Barocchi, Preface Two, III, pp. 4, 8, and 12.
} 


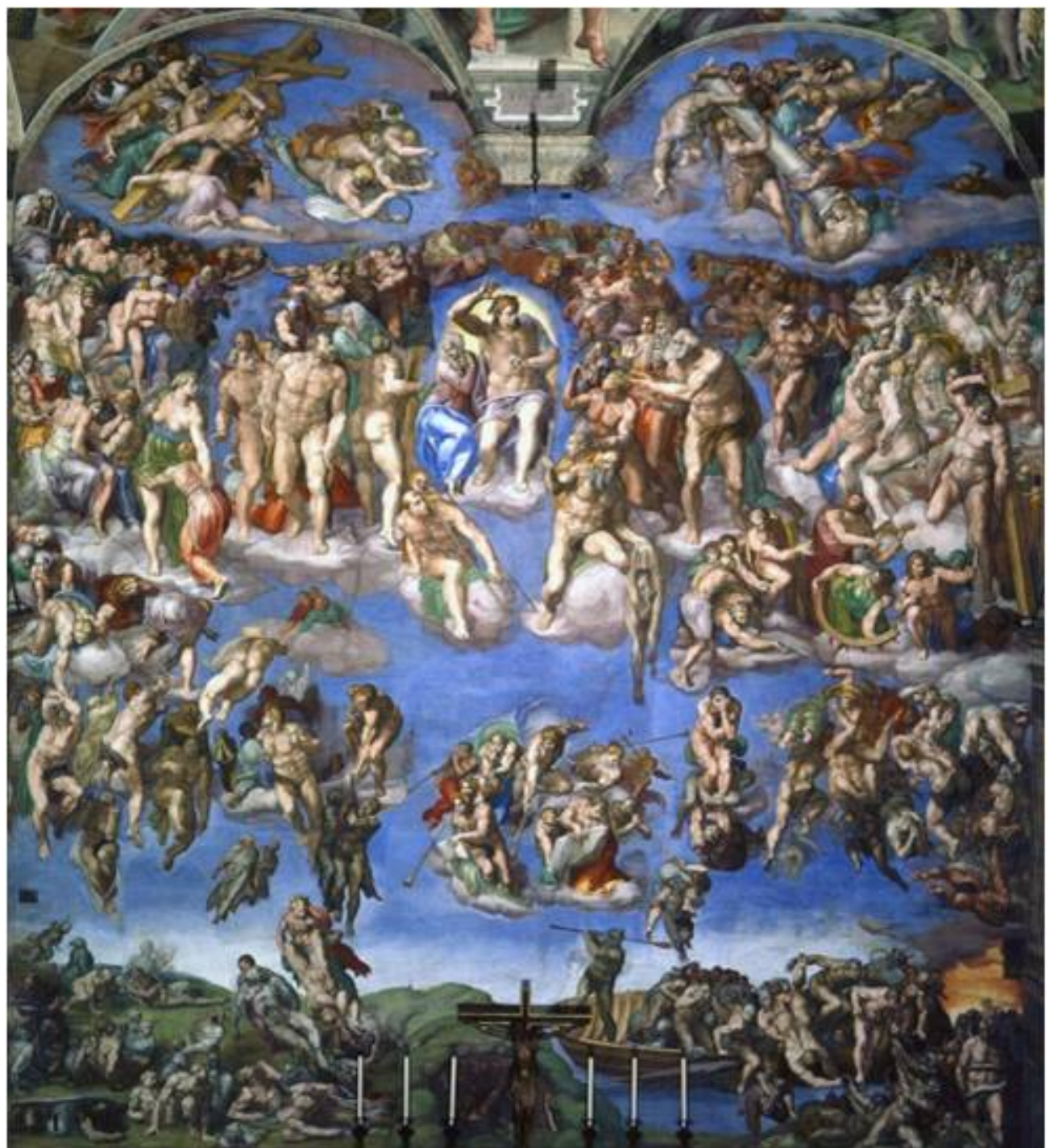

Figure 4. Michelangelo, Last Judgment, 1541-1543, Sistine Chapel, Vatican. (Photo credit: Public Domain, wikepedia.org)

Vasari continues with the Cinquecento tradition of immortalizing artists and their art with paintings of the personifications of the Fine Arts as Painting, Sculpture and Architecture, as seen in the Fine Arts of the endpiece. $^{36}$ This theme fascinated him, since he repeats this imagery in the Chamber of Fame in 1542 in his house at Arezzo (see Figure 5). He provides a general characterization of this ceiling in his autobiography: "I painted (on the ceiling) all the Arts connected with design or dependent on design. In the middle Fame, seated

\footnotetext{
${ }^{36}$ A personification of the Fine Arts is common in the humanistic art of the Italian Renaissance, with examples including Pisani’s pulpits, the reliefs on Giotto's Campanile, the reliefs on the Ducal Palace in Venice, the lost frescoes of the Eremitani in Padua, the Spanish Chapel in Florence, and later the figures in the Tempio Malatestiano, Pollaiuolo’s Papal Tomb and Dosso's Sala del Tribunale in Trento. See J. von Schlosser, “Giustos Fresken in Padua und die Vorläufer der Stanza della Segnatura,” Jahrbuch der kunsthistorischen Sammlungen des allerhöchsten Kaiserhauses 17 (1896), pp. 13-100; P. D’Ancona, "Le rappresentazioni allegoriche delle arti liberali," L'Arte (1902), here pp. 13, 137, 221-227, in particular, 269-289 and 370-385; Raymond van Marle, Iconografie de l'art profane au moyen-âge et a la Renaissance (Hague: Martinus Nijhoff, 1932), II, pp. 203-206; L. Reau, Iconographie del 'Art Chrétien (Paris: Presses universitaries de France, 1955-1959), I, pp. 154-162; and F. Gibbons, Dosso and Battista Dossi (Princeton: Princeton University Press, 1968), pp. 52-53, for an interesting discussion on the Liberal Arts.
} 
on a terrestrial globe, blows one golden trumpet with one hand and discards another into a fire with the other hand, this latter trumpet symbolizes slander." ${ }^{37}$ Around her are all the Arts, with their attributes, including the personification of Poetry, actively engaged in their fatica (labor). In his Florentine house, in the walls of the sala (1561), Vasari repeats the same imagery of the Fine Arts, but adding the personification of Music and including the personification of Fame.
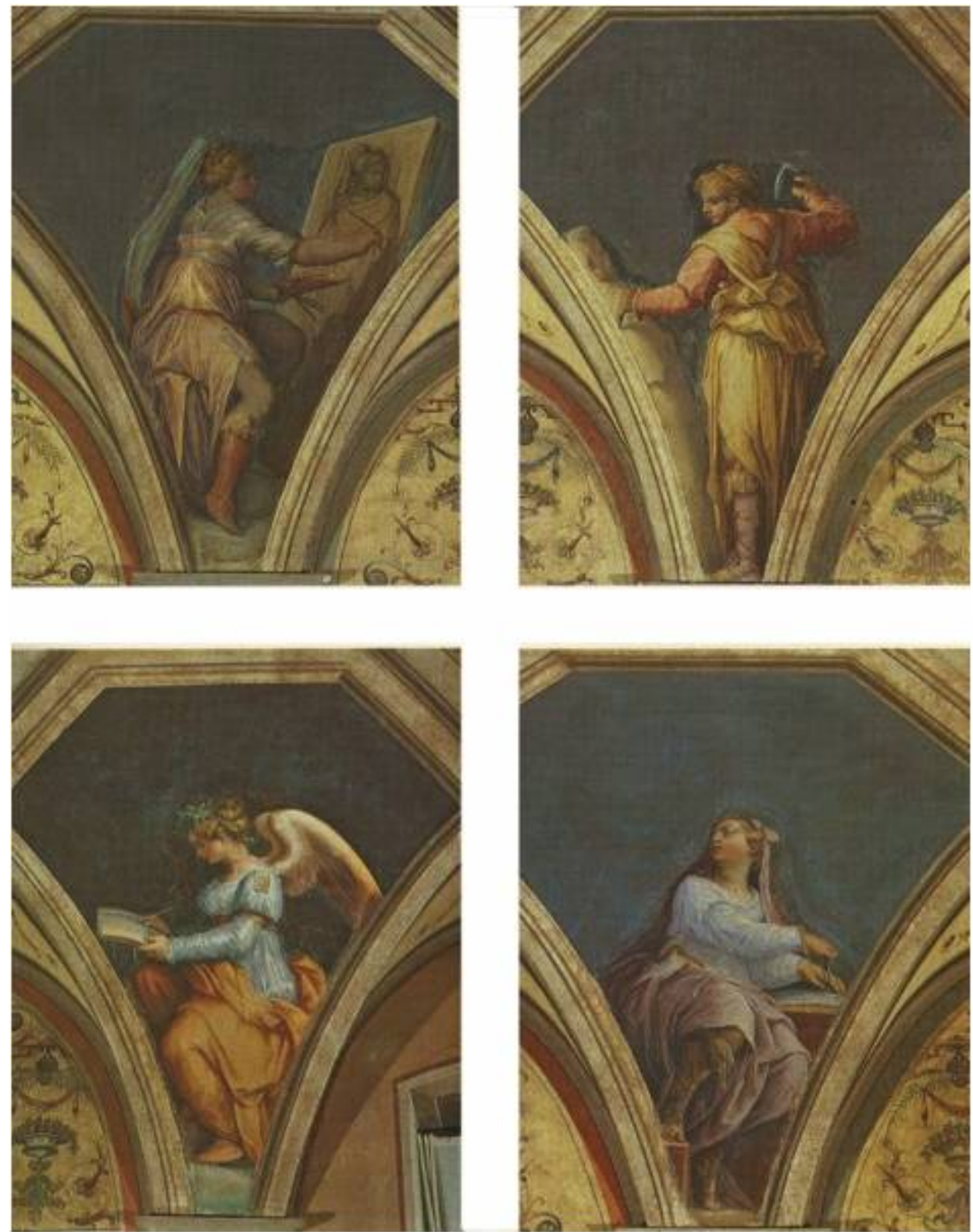

Figure 5. Giorgio Vasari, Fine Arts 1542, Chamber of Fame, Casa Vasari, Arezzo. (Photo credit: Liana De Girolami Cheney)

\footnotetext{
${ }^{37}$ Bettarini-Barocchi, Vasari’s vita, p. 382.
} 
Vasari's artistic conceptions are associated with the notion of artistic recognition or fame (Fama), as he visualizes it in the endpiece. ${ }^{38}$ At the top level of the endpiece, in the celestial realm, a floating, winged figure of Fame holds her instruments of attribution, a trumpet and a torch. Vasari describes his depiction of Fame as having "the trumpet in the mouth, the one of fire in hand, and the world below" ("la tromba in bocca, quella di fuoco in mano, il mondo sotto") as seen in depiction of the Allegory of Fame of 1542, in the ceiling of Chamber of Fame in the Casa Vasari in Arezzo (see Figure 6). ${ }^{39}$ He further explains that the personification of Fame "sings and praises the deeds of the virtuous." 40

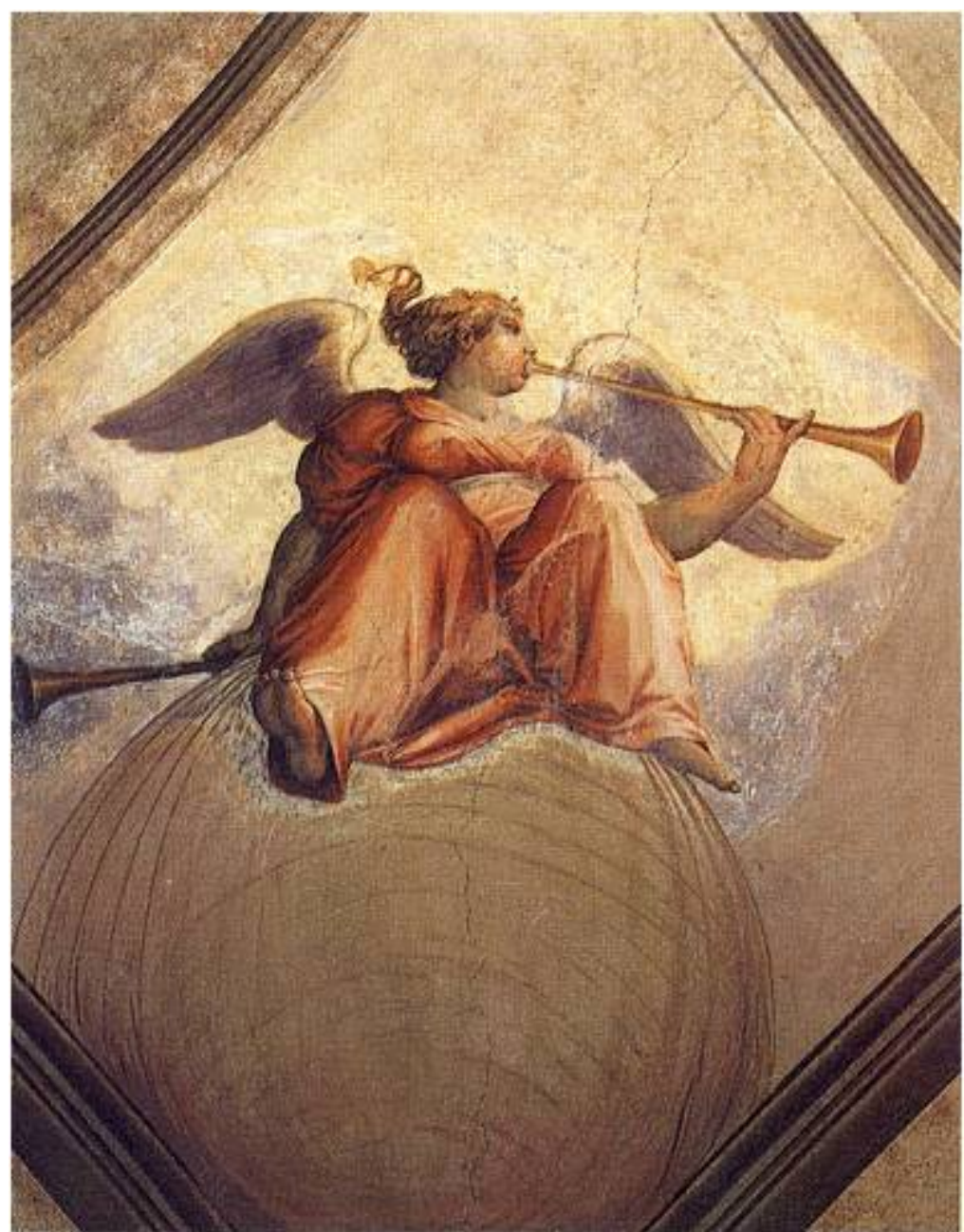

Figure 6. Giorgio Vasari, Fame, 1542, ceiling det. Chamber of Fame, Casa Vasari, Arezzo. (Photo credit: Liana De Girolami Cheney)

\footnotetext{
${ }^{38}$ Vasari depicts this motif also in painting. For example, in the Aretine chamber, Painting is depicting a portrait of a man holding a scroll (the poet Dante), whereas in the Florence Sala, Vasari depicts Painting portraying an orator. See Cheney, The Homes of Giorgio Vasari, for illustrations, p. 212, Fig. 12; and p. 257, Fig. 57, respectively.

39 Alessandro del Vita, Lo Zibaldone di Giorgio Vasari (Rome: R. Istituto Archeologico e Storia dell'Arte, 1938), p. 24.

40 See Gaetano Milanesi (Ed.), Le vite de’ piú eccellenti Pittori, Scultori, et Architettori (Florence: G. C. Sansoni, 1970-1974), VIII, p. 60. I Ragionamenti is not included in Bettarini-Barocchi.
} 


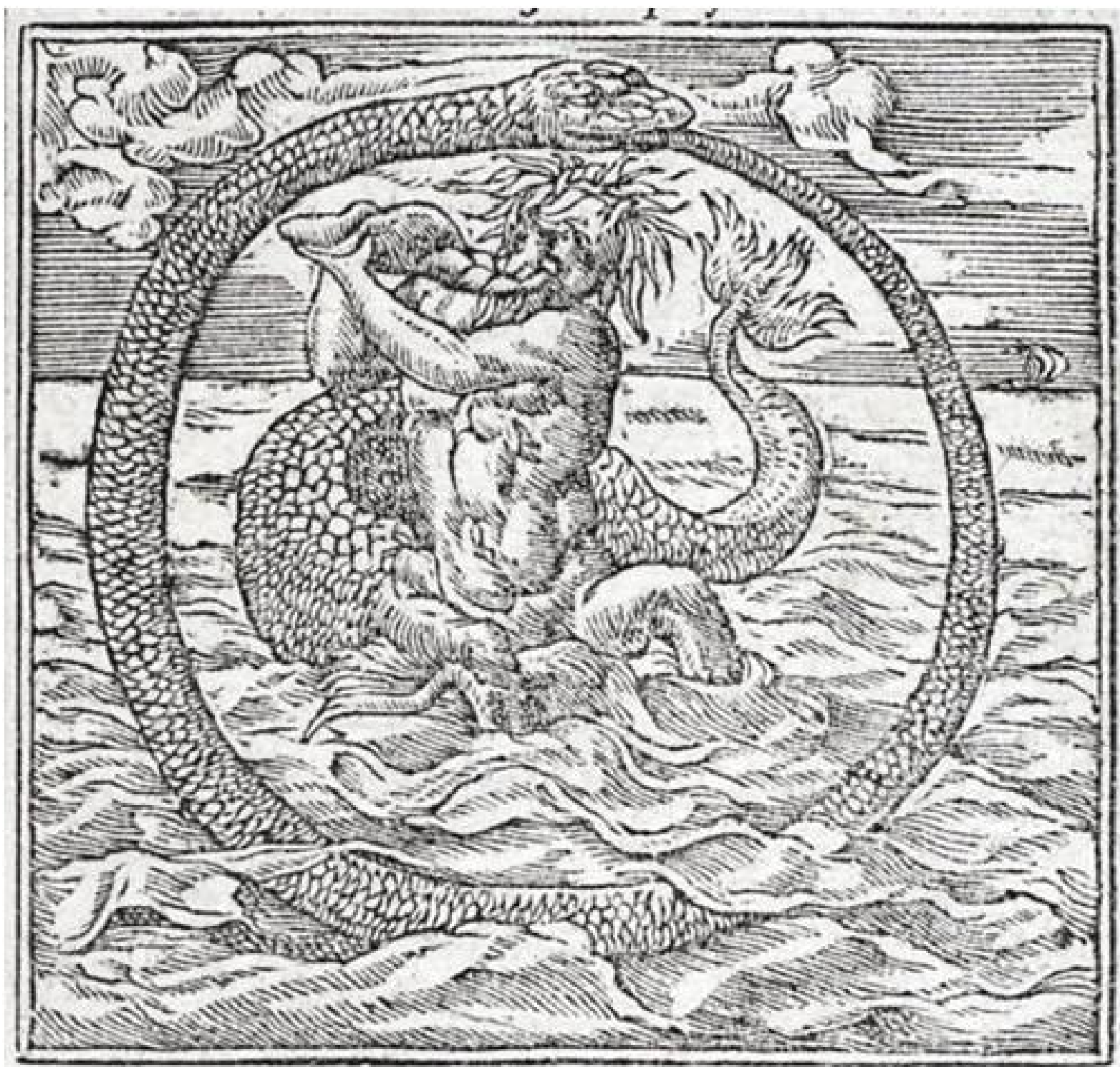

Figure 7. Andrea Alciato, Emblem 119, from Emblemata (Diverse Imprese) in Lyons: Macé Bonhomme for Guillaume Rouille 1551. (Photo credit: Glasgow University Library, SM35A)

In part, Vasari's conceit for this personification draws on the traditional Cinquecento depiction, which represents Fame as winged, bare-breasted, seated or standing on a globe and, most importantly, holding up two trumpets (Polidoro da Caravaggio), or blowing a trumpet (Francesco Salviati). ${ }^{41}$ However, in the endpiece, Vasari's Fame, announcing affirmation of success, relies on her forceful act of blowing. This imagery is reminiscent of Andrea Alciato's Honore (Honor), Emblem 119, in the Emblemata of 1551 (see Figure 7), which illustrates in the pictura Triton, nude to the waist, floating on the sea, while energetically blowing on a conch. Triton is encircled by a snake biting its own tail (oroburos). The composition alludes to universality and

\footnotetext{
${ }^{41}$ Polidoro da Caravaggio's Fame from the Salone of the Villa Lante (now in the Bibliotheca Hertziana) and Francesco Salviati's Fame from the fresco cycle of the Sala dei Fasti Farnesiani in the Palazzo. For illustrations, see Pierluigi Leone de Castris, Polidoro Da Caravaggio (Naples: Electa, 2001), n.p.; and Luisa Mortari, Francesco Salviati (Rome: De Luca, 1992), p. 55, catalogue entry 36.
} 
the eternal power of the sound of honorific deeds. The motto reads in Latin "Ex literarum studiis immortalitatem acquire" and in Italian "Che per li studi di lettere l'houmo si fa immortale” ("That man gains immortality through literary pursuits”), and the text or epigram reinforces the didactic message of the emblem.

Triton, a Neptune's trumpeter, whose tail shows him as a sea-monster, his face as a god of the sea, is surrounded by an encircling snake, which bites on its own tail, gripped fast in its mouth. Fame follows after men of outstanding intellect and their noble achievements, and bids them be read throughout the world. ${ }^{42}$

Vasari appropriates not only Alciato's emblem in the endpiece but also Michelangelo's trumpeters in the Last Judgment of 1541-1543 in the Sistine Chapel, thus recalling a Judgment Day. Although the Last Judgment association appears to be negative in part for those beings who performed evil actions, Vasari transforms Michelangelo's depiction as benevolent, alluding to the eternal recognition of artists' creative deeds, following Alciato's dictum in his emblem.

Vasari metaphorically depicts an artistic and a symbolic transformation of the light in the background of the print's design by composing at the top of the design a large semi-circular area, and below it another area filled with drawn lines. The light of the torch accentuates a transformation that is artistic and symbolic. Artistically, for example, one observes that at top of the design, the flames of the torch shed the strongest light, which is dazzling. Vasari represents this luminary area by composing a wide-open area devoid of lines in the design. As the radiance of the light emanates downward, thick-hatched lines appear in the design, signifying that the wide lines are equal to rays of light. These lines transform into beams of luminosity, revealing the presence of the Fine Arts in the center of the composition. As they move downward, the hatched lines become longer and thinner, suggesting a diffused and dim light. This light reveals a space crowded with human forms, the realm of the dead. Vasari employs fine and thick hatching lines to capture darkness in the abysm of oblivion where the deceased artists now reside.

Iconologically, for Vasari, Fame takes on a dual role, since she blows a trumpet and holds a burning torch. This duality consists of Fame being both judge and illuminator. When Fame blows the trumpet, she symbolizes artistic judgment and affirmation of success. As she holds a flaming torch, Fame becomes an illuminator of Glory. In her affirmative role, Fame blows the trumpet in the direction of the personification of Sculpture while illuminating with her torch the area of Painting. ${ }^{43}$ Furthermore, the semi-circular open area behind Fame is an allusion to the sun, and the drawn lines a reference to the sun's radiation, thus depicting a celestial vision of radiance and emanation. Vasari portrays Fame as a divine messenger and inspirational guide. She holds a blowing torch, which refers to her ability to obtain natural light from celestial light. This Vasarian parallelism is between the physical (burning torch) and metaphysical (sun’s rays) realms or between human visualization and divine inspiration.

Vasari's depiction of the Fine Arts in the endpiece expresses the Cinquecento artist's sentiments regarding the aim, value and status of both the artist and the arts. Art is no longer considered a craft based on imitation and technique but, rather, a noble humanistic endeavor requiring invention. Likewise, the artist is to be

\footnotetext{
${ }^{42}$ Andrea Alciato, Emblemata (Venice: Aldus, 1551), Emblem 119, Honore (Honor). The text of the emblem says: “Tritone, ch’è; Trombetta di Nettuno, / E mezzo pesce, e mezzo forma humana, / Lo cinge un Serpe \& gli fa cerchio intorno, / Che ne la bocca tien la coda stretta. / Cola buona fama, che d'alcuno / Abbraccia qualche degna opera eletta. / In ogni parte va suonando il corno / Del mondo o sia vicina, o sia lontana."

${ }^{43}$ Cesare Ripa, Iconologia, Erna Mandowsky (Ed.) (New York: George Olms Verlag, 1970), p. 302, for another type of Fame.
} 
regarded not as artisan or laborer but as a creative, educated being and a member of an intellectual society. ${ }^{44}$

The artist who would fully pursue this enhanced status must endeavor to demonstrate the qualities and capacities presented by Baldassare Castiglione in The Book of the Courtier (1517). ${ }^{45}$ Castiglione notes that it is the touch of fame and glory upon one's life that establishes a reputation and immortality. ${ }^{46}$ Among the requirements securing and enhancing one's status as a gentleman are knowledge of the liberal arts, especially painting, the construction of a memorial—preferably in design— to one's achievements ${ }^{47}$ and the possession of personal nobility achieved through one's ancestry, deeds and personal attributes. ${ }^{48}$

In many respects, the endpiece of 1550 is a testimony to this social and cultural upgrading of art and the artist. It demonstrates that Vasari heeds the counsel of Castiglione, where he honors artists as well Panting as a Fine Arts. Castiglione writes:

Dir si puo che una nobile e gran pittura sia, per mano della natura e di Dio composta; la qual chi po imitare, parmi esser di grand laude degno: nè a questo pevenir si puo senza la cognizione di molte cose, come ben sa chi la prova.

(May be said to be a great and noble picture, composed by the hand of nature and of God; and whoever is able to imitate it, seems to me deserving of great praise: nor can it be imitated without knowledge of many things, as he knows well who tries). ${ }^{49}$

Vasari manifests the same sentiment by the fruits of his artistic and literary talents in depicting the Fine Arts in the endpiece in the first edition of the Vite and in his writing in Preface Three:

Aggiugnendo alle cose de' primi regola, ordine, misura, disegno e maniera se non in tutto perfettamente, tanto almanco vicino aI vero, che i terzi, di chi noi ragioneremo da qui avanti, poterono mediante quel lume sollevarsi e condursi alla somma perfezzione, dove abbiamo le cose moderne di maggior pregio e più celebrate.

(Rule, order, proportion, design and manner, have all been added by them to the characteristics exhibited by those of the first period, if not in the utmost perfection, yet making so near an approach to the truth, that the masters of the third period, of which we are henceforward to treat, have been enabled, by the light thus afforded them, to reach that summit which the best and most renowned of modern works prove them to have attained.) $)^{50}$

A unique study for a frontispiece for the Vite or for Michelangelo's vita in Anthony Blunt's collection reveals Vasari's quest for disegno and its manifestation in the Fine Arts (see Figure 8).

\footnotetext{
44 See Bettarini-Barocchi, Vasari's Letter to the Artists of Disegno, I, p. 176, and Letter of 1550 to Cosimo I de' Medici, Duke of Florence, I, p. 1.

${ }^{45}$ See Rubin, Giorgio Vasari, pp. 52 and 166; and T. S. R. Boase, Giorgio Vasari: The Man and the Book (Princeton: Princeton University Press, 1971), pp. 124 and 236.

${ }^{46}$ See Baldassare Castiglione, The Book of the Courtier, George Bull (Trans.) (Baltimore, MD: Penguin Books, 1967), p. 92; Rubin, Giorgio Vasari, pp. 358 and 378.

47 Castiglione, The Book of the Courtier, pp. 96-97.

48 Castiglione, The Book of the Courtier, p. 56.

49 See Baldassare Castiglione, Il Corteggiano, ed. rep. 1528 (Milan: Silvestri, 1822), Book One, p. 119, for the Italian version. See also Leon Battista Alberti, Della Pittura, L. Mallè (Ed.) (Florence: Sansoni 1950), pp. 76-77 and 80, for similar comment on the universality of painting.

50 Bettarini-Barocchi, Preface Three, IV, p. 4.
} 


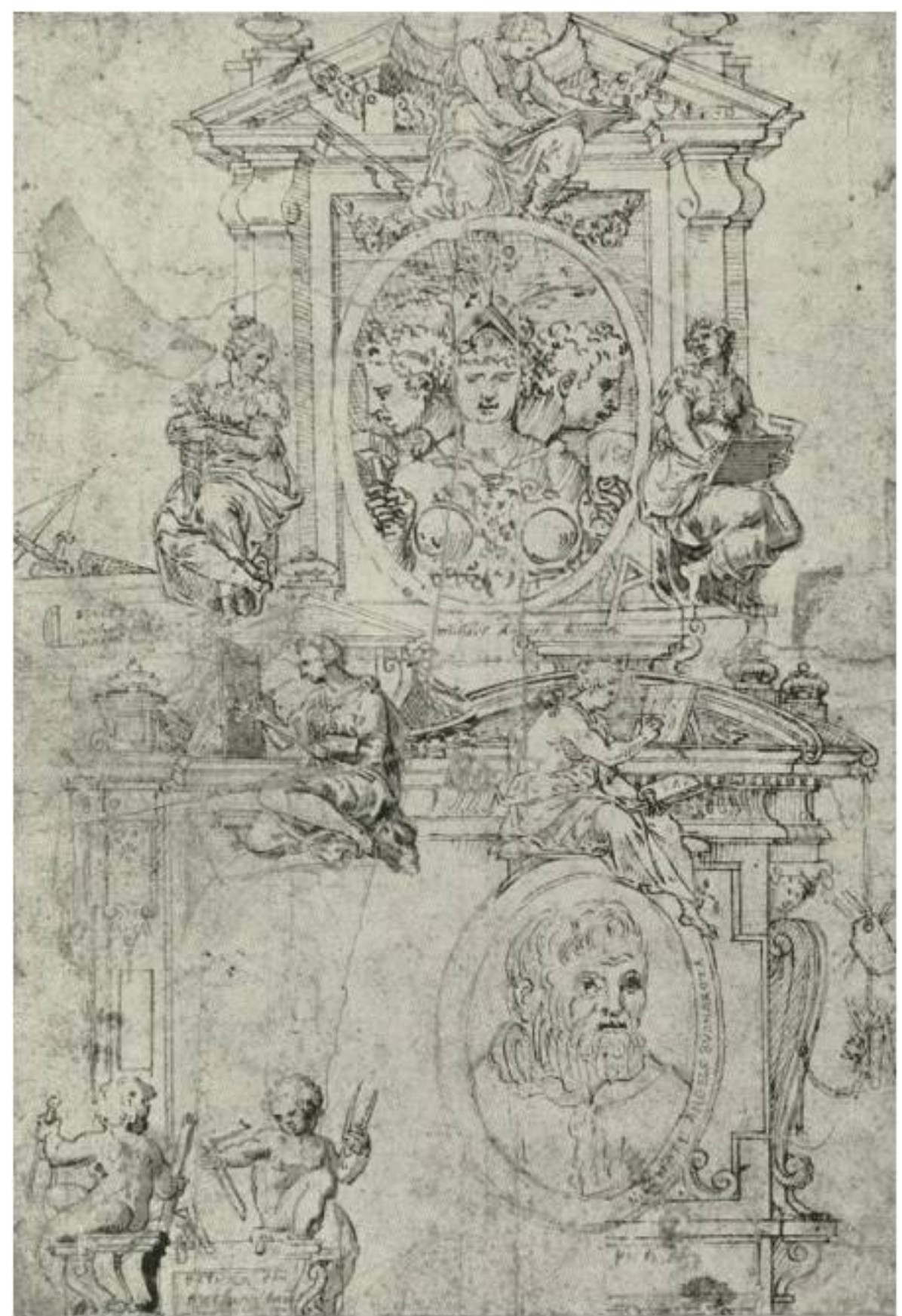

Figure 8. Giorgio Vasari, Study for the Frontispiece of the Vite, c.1555, drawing. Anthony Blunt Collection, London. (Photo credit: From Laura Corti, ed., Principi, Letterati e Artisti nelle Carte di Giorgio Vasari (Florence: EDAM, 1981), Section VIII, 15)

The personification of Disegno is engaged in the act of drawing. She stands at the top of a medallion containing the trio of sister arts at bust length. Vasari's desire to integrate the Fine Arts with the relevant creative and artistic skill of the artists is seen in the cartouche of his vita (see Figure 9), for example, where the personifications of painting and architecture are added to the design. In addition, in his collection of artists' drawings for his Libro de' Disegni (see Figure 10), Vasari once again designs a cartouche with the artist's 
attributes, surrounding the imagery with actual drawings of the artist. ${ }^{51}$

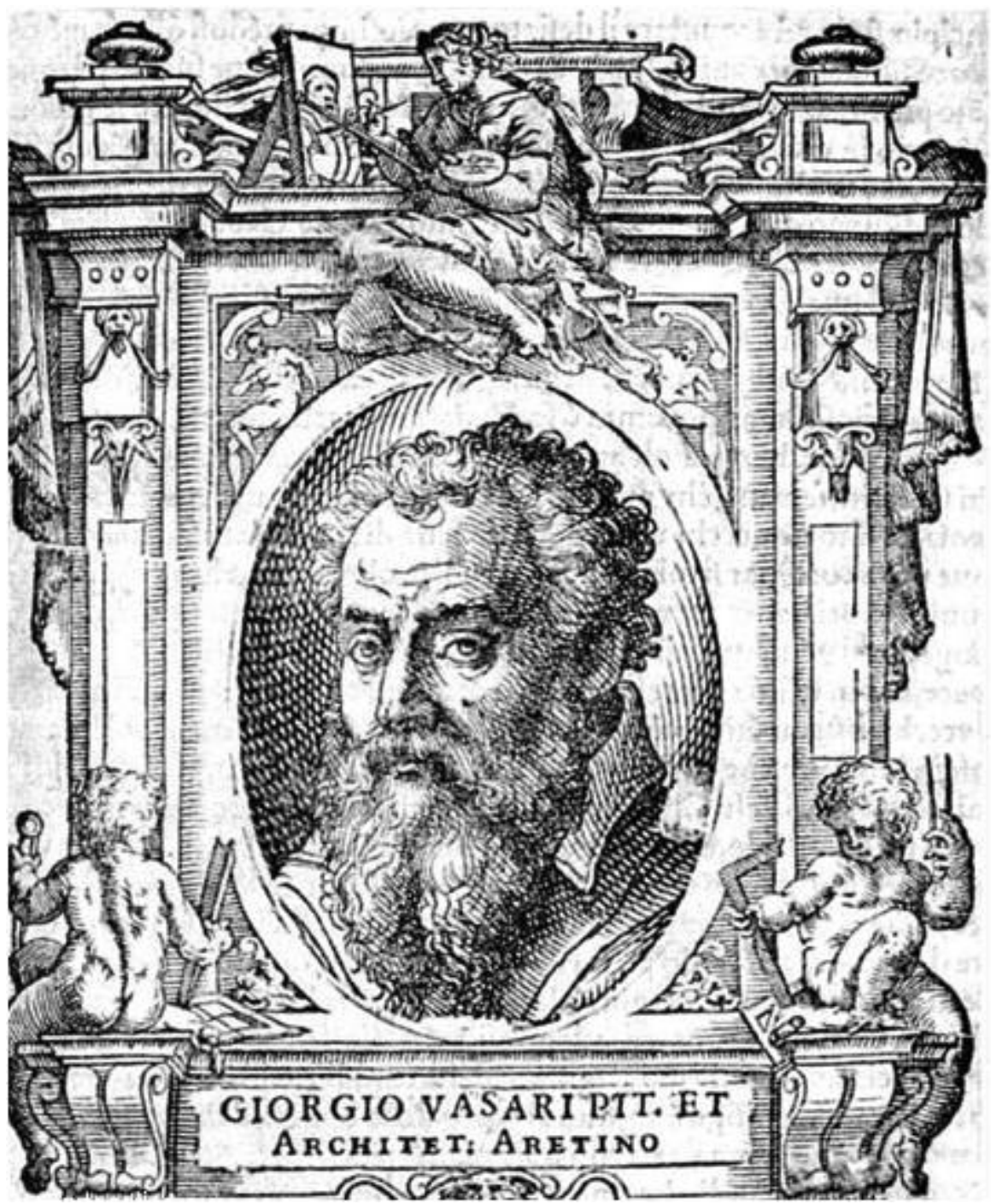

Figure 9. Giorgio Vasari, Cartouche of 1550s, in the Vite of 1568 edition. (Photo credit: Public Domain, xylography)

\footnotetext{
51 This album of drawings forms a virtual history of drawings from Cimabue's time to Vasari's, and its content reveals the interdependence between drawing and the creation of the visual arts. Vasari is a collector of art as well. His collection of drawings illustrates the styles of the artists about whose lives he is writing. In part, he inherits a collection of drawings from a descendant of Lorenzo Ghiberti in 1528. The Libro de’ Disegni is frequently mentioned in the Vite. See Bernhard Degenhart, "Zur Graphologie der Handzeichnungen,” in Kunstgeschichtliches Jahrbuch der Bibliotheca Hertziana 1 (1937), pp. 223-343; Bernhard Degenhart and Annegrit Schmitt, "Methoden Vasaris bei der Gestaltung seines Libro, "Studien zur toskanischen Kunst. Festschrift für L. H. Heydenreich (Munich: Georg Müller, 1964), pp. 45-65; Licia Collobi-Ragghianti, Il Libro de’ Disegni del Vasari (Florence: Vallecchi, 1974), 2 vols.; and Per Bjurström, Italian Drawings from the Collection of Giorgio Vasari (Stockholm: Nationalmuseum, 2001), passim. Here, the image in Fig. 10 is a folio of the Libro de' Disegni, containing five drawings attributed to Filippino Lippi, in the Collection of Christ Church, Oxford, England.
} 


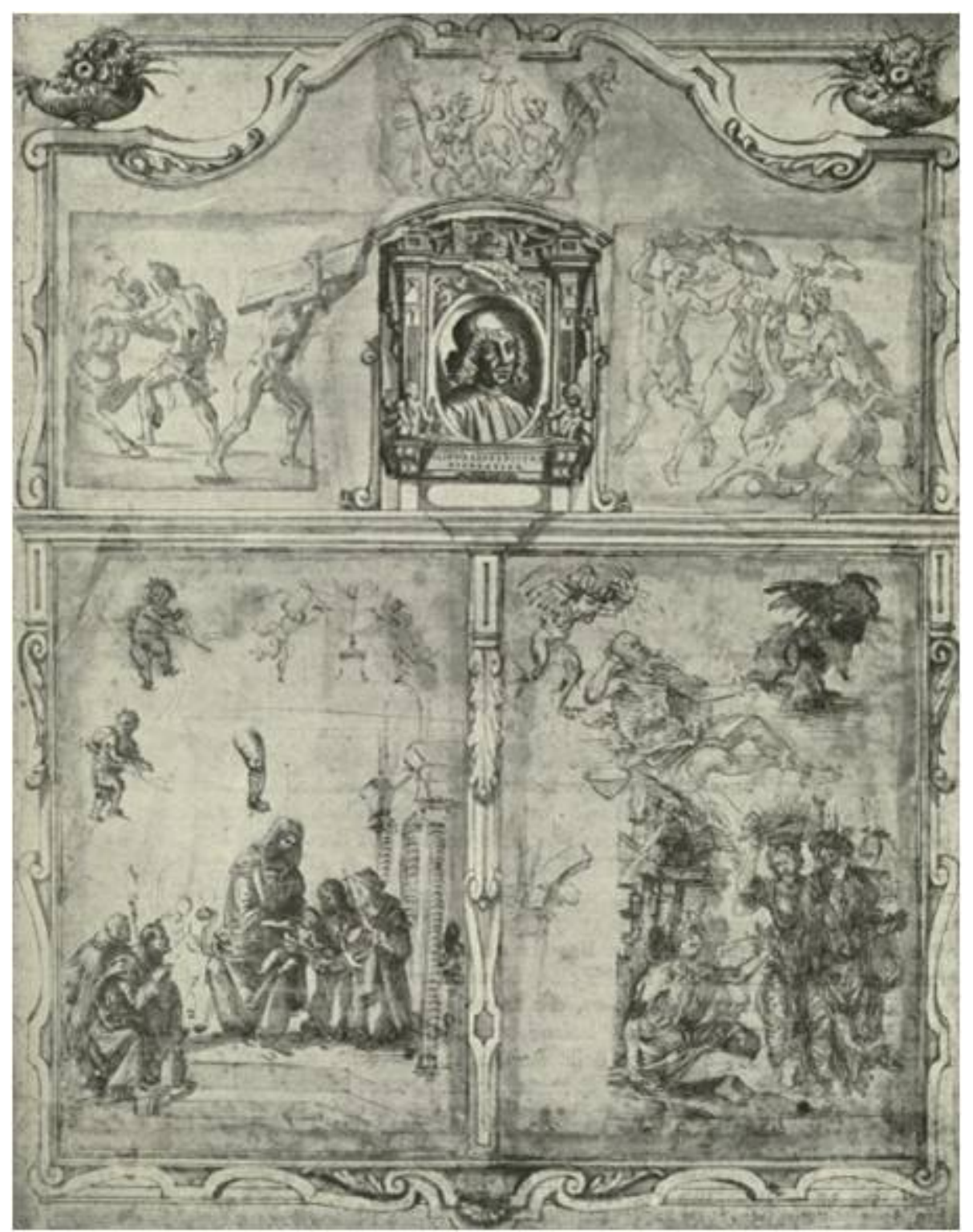

Figure 10. Giorgio Vasari, Folio from Libro de' Disegni, drawing. Christ Church, Oxford, England. (Photo credit: Christ Church, Oxford, England)

In describing the function of the Fine Arts in his imagery, Vasari stresses the element of disegno (drawing or design) as the underlying quality that unites them. ${ }^{52}$ With the same quest of creating a unified imagery with the three elliptical shapes for the external composition of the Fine Arts, Vasari conceptually employs the element of disegno to bond the formation of the Fine Arts. As he notes in the First Preface of the second edition of the Vite: "Ma io diro bene che dell'una e dell'atra il disegno-che è il fondamento di quelle" ("But I will surely say that of both one and the other of these arts the design [painting, sculpture and architecture] which is their foundation”). ${ }^{53}$ He continues with this idea, explaining what he means by disegno and why it rules creation in the Fine Art.

\footnotetext{
52 See Roland Le Mollé, Georges Vasari: et le vocabulaire de la critique d’art dans les “Vite” (Grenoble: Ellug, 1988), pp. 19-42, for an original discussion on Vasari's concept of unione (union) in the Vite.

${ }^{53}$ See Bettarini-Barocchi, Preface One, II, p. 3.
} 
Perchè il disegno padre delle tre arti nostre, Architettura, Scultura e Pittura, procedendo dall'intelletto, cava di molte cose un giudizio universale; simile a una forma ovvero idea di tutte le cose della natura... E perchè questa cognizione nasce un certo concetto e giudizio, che si forma nella mente quella tal cosa che poi espressa con le mani si chiama disegno; si può conchiudere che esso disegno altro non sia che un apparente espressione e dichiarazione del concetto che si nell'idea.

(Seeing that Design, the parent of our three arts, Architecture, Sculpture and Painting, has its origin in the intellect and draws out from many single things a general judgment, it seems like a form or idea of all the objects in nature... Afterwards, when it is expressed by the hands and is called Design; we may conclude that Design is none other than a visible expression and declaration of our inner conception and of that which others have imagined and given form to in their ideas). ${ }^{54}$

Vasari goes on to observe that in the Fine Arts:

Disegno ... servono così all'architettura e scultura come alla pittura: all'achitettura perciò che I disegni di quella non sono composti se non di line: il che non è altro, quanto all'architettore, che il principio e la fine di quell'arte... Scultori in cambio, con bella proporzione e misura fanno il medesimo che fa colui ... disegno in vari modi ... quegli poi che hanno le prime line intorno, sono chiamati profili, dintorni o lineamenti. E tutti questi, o profili ... Nella pittura servono i lineamenti in più modi ma particolarmente a dintornare ogni figura; perchè quando egli non sono ben disegnati e fatti giusti ed a proporzione, l’ombre che poi vi si aggiungono e i lumi, sono cagione che i lineamenti della figure che si fa, ha gradissimo rilievo, e riesce di tutta bontà e perfezione.

([The chief use of] disegno (design) in Architecture is because its designs are composed only of lines, which so far as the architect is concerned are nothing else but the beginning and the end of his art... For sculptors [In Sculpture], drawing (design) is of service in the case of all the profiles, because in going round from view to view the sculptor employs design when he wishes to delineate the forms which please him best, or which he intends to bring out in every dimension... In Painting, the lines are of service in many ways, but especially in outlining every figure, because when they are well drawn, and made correct and in proportion, the shadows and lights that are then added give the strongest relief to the lines of the figure and the result is all excellence and perfection.) ${ }^{55}$

In further observing the geometrical composition of Vasari's endpiece, inside the oval shape, there is an abstract and dominant isosceles triangle revealed in the formation a base line at the feet of the Fine Arts and two diagonal lines culminating above Fame's head. In reference to Vasari's art and writings, this triangular design maybe viewed as symbolic of a threefold division of humanistic and divine aspects in the universe, namely, in the arts, e.g., painting, sculpture and architecture; compositional design in all art forms, e.g., disegno, invention and imitation; and in the writing of Vite as in the biological stages, e.g., childhood, adolescence and adulthood or first, second and third period of the artists' careers. In terms of divine aspects, the threefold association is connected with creativity, God, inspiration and artist; or nature, artist and God.

In Vasari's endpiece, the apex of this imaginary triangle connects with the top area of the print, which symbolizes the sun, with its emanating heat, composed by rays of line, symbolic of rays of light. This celestial light reveals a fiery illumination. According to Jean Chevalier and Alain Gheerbrant, for the Pythagoreans as well as ancient alchemists, the triangle is a symbol of fire associated with the natural form of a mountain and

\footnotetext{
54 Roberto Panichi, La Tecnica dell'arte negli scritti di Giorgio Vasari (Florence: Alinea, 1991), pp. 83-84; Louisa S. Maclehose (Trans.), Gerard Baldwin Brown (Ed.), Vasari on Technique (New York: Dover Publications, Inc., 1960), pp. 205-207; and Paola Barocchi (Ed.), Scritti d'Arte del Cinquecento: Disegno, VIII (Turin: Giulio Einaudi, 1979), pp. 1912-1913. See also E. H. Gombrich, "A Classical Topos in the Introduction to Alberti’s Della pittura," Journal of the Warburg and Courtauld Institutes, 20 (1957), p. 173, where he considers Nature "Mistress of all things."

${ }_{55}$ Panichi, La Tecnica dell'arte negli scritti di Giorgio Vasari, pp. 83-84. This tome only examines the original writings of Vasari’s Alle Tre Arti del Disengo: Architettura, Scultura e Pittura. Bettarini-Barocchi, I, pp. 31-172, in particular, pp. 111-112.
} 
with God's divinity. ${ }^{56}$ Earlier in the essay, I discussed the placement of the Fine Arts on a mountaintop, the mountain of the Muses; here, the association is further accentuated by noting their placement in a pyramidal or triangular design. At the apex this mountain or triangular shape, celestial fiery sparks or beam of lights are represented in the imagery by the formation of diagonal lines behind the Fine Arts and the open area above them. The metaphorical allusion of the fiery sparks maybe compared to the Platonic notion of furor (frenzy). ${ }^{57}$

In the endpiece, Vasari visualizes the bond among the Fine Arts by depicting them together, holding their corresponding artistic instruments (chisel for Sculpture, compass and ruler for Architecture and brush and palette for Painting) in order to compose a work of art through disegno, which is inspired or conceived through divine inspiration or an intellectual or artistic frenzy. Vasari depicts the Fine Arts cogitating as Sculpture looks at her sculptural model, Architecture raises her head for inspiration, while holding her instrument of labor, and Painting pensively rests her head on her bent arm while holding a palette and a brush with the other. At her feet, small containers of paint might suggest her deliberation in the selection of colors for the paintings.

In his writings, Vasari relates the creation of the Fine Arts or visual arts to the concept of artistic frenzy:

E chi sa che l'arti del disegno, per non dir la pittura, sono alla poesia simili, sa ancora che come le poesie dettate dal furore poetico sono le vere e le buone e migliori che le stentate, così l'opere degli uomini eccellenti nell'arti el disegno sono migliori quando sono fatte a un tratto dalla forza di quel furore che quando si vanno ghiribizzando a poco a poco con istendo e con fatica.

(And he who knows that the arts of design [Fine Arts], not to speak only of painting, are similar to poetry, knows as well that as poems are imposed by poetic furor are true and better than those belabored, so too, the works of men excellent in the arts of design are better when they are made under the stroke of power of that furor, that when they are whimsically drifted little by little with effort and labor). ${ }^{58}$

In this statement, Vasari is interpreting the Renaissance Neoplatonic concept of furor poeticus or poetic inspiration, which derives from the writings of philosopher Marsilio Ficino. Ficino explains in his Orphic writings that there are four forms of inspiration or furor: divine, prophetic, amorous and poetic. ${ }^{59}$ Considering Ficino's philosophical influence in the arts as well as on Vasari, I would like to coin Vasari's inspirational fire as a particular type of furor, a furor artisticus, a unique artistic frenzy of visual artists. ${ }^{60}$ Vasari's explanation of artistic inspiration is based fundamentally on the Italian Renaissance tradition, which considers creativity to

\footnotetext{
56 Jean Chevalier and Alain Gheerbrant A Dictionary of Symbols, trans. John Buchanan-Brown (Oxford: Basil Blackwell, Ltd., 1994), p. 1034. In the Timaeus (53b2-53c), Plato discusses his cosmology reflecting on a Craftsman constructing triangles associated with the elements of fire, water, earth and air. See Benjamin Jowett, The Collected Works of Plato (Princeton: Princeton University Press, 1980), pp. 1179-1180.

57 See Michael J. Allen, The Platonism of Marsilio Ficino (Los Angeles, CA: University of California Press, 1984), pp. 41-67, for a reference to the four types of divinus furor in Ficino's writings, in particular, in his Commentary on Plato's Symposium (7:14): "The four divine furors are first poetical, then mythical, third prophetic and amorous fourth" ("Quatuor ergo divini furoris sunt speties. Primus quidem poeticus furor, alter mysterialis, tertius vaticinium, amatorious affectus est quartus”). See also Paul Oskar Kristeller (Ed.), The Letters of Marsilio Ficino, 3 vols. (New York: Ginko Press, 1985), I, pp. 14-20, and Marsilio Ficino’s letter to Peregrino Agli on De divino furore.

${ }^{58}$ Bettarini-Barocchi, III, p. 52.

59 See Sears R. Jayne, “Ficino and the Platonism of the English Renaissance,” Comparative Literature, vol. 4 (Summer 1952), pp. 214-238; Michael J. B. Allen, Marsilio Ficino and the Phaedran Charioteer (Los Angeles, CA: University of California Press, 1981), pp. 339-439; and Allen, The Platonism of Marsilio Ficino, pp. 41-67.

${ }^{60}$ André Chastel, Marsile Ficin et L'Art (Geneva: Droz, 1975), pp. 129-133, chapter on “Furor divinus: L'inspiration.”
} 
be a faculty present in all of human activity. ${ }^{61}$ He explains, "Thus [creativity must be activated] when the intellect (l'ingegno) wants to work, and when the fire of inspiration is kindled (il furore e acceso), because it is then that one sees excellent and divine results, and marvelous conceptions (concetti meravigliosi).”62

These notions about artistic creativity combine with the conception of poetic inspiration in relation to yet another central idea, ut pictura poesis ("as is painting, so is poetry"). ${ }^{63}$ Derived from Horace, the phrase is frequently employed by artists and theoreticians of the sixteenth-century (Cinquecento), including Leonardo da Vinci, Ludovico Dolce, Gian Paolo Lomazzo and Vasari himself. ${ }^{64}$ The idea of ut pictura poesis captures the complementary nature of poetry or writing with painting, equating the inspiration of the poet and writer with the imagination of the painter. ${ }^{65}$ Both are concerned with the imitation of nature: the painter through the use of visual elements line, color, tone, texture and shape; the poet or writer through words. Leonardo, commenting on the versatility of the painter, remarks about this parity:

\footnotetext{
${ }^{61}$ See The Letters of Marsilio Ficino, Preface by Paul Oskar Kristeller, translated and edited from Latin by members of the Language Department of the School of Economic Science in London (no names), 3 vols. (New York: Gingko Press, 1975-1978), vol. 1, Letter 7, Marsilio Ficino to Peregrino Agli, On Divine Frenzy, pp. 14-20 (no date, probably between 1457 and 1476); Marsilio Ficino, Meditations on the Soul: Selected Letters of Marsilio Ficino, Clement Salaman (Ed. and Trans.) (Rochester, VT: Inner Traditions International, 1996), pp. 64-70, on divine frenzy; Thomas Moore, The Planets Within (Hudson, NY: Lindisfarne Press, 1990), pp. 41 and 86-87; and D. P. Walker, Spiritual and Demonic Magic: From Ficino to Campanella (University Park, PA: The Pennsylvania State University Press, 2000), pp. 3-11.

62 Bettarini-Barocchi, III, p. 62. “Attesoché l’ingegno vuol essere affaticato quando l’intelleto ha voglia di operare, e che il furore è acceso, perché allora si vede uscirne parti eccellenti e divini, e concetti meravigliosi.”

${ }^{63}$ Michael J. B. Allen, Marsilio Ficino and the Phaedran Charioteer, pp. 339-439; and Chastel, Marsile Ficin et L'Art, pp. 81-89.

${ }^{64}$ The phrase originate from Horace's Arts poetica (line 361), first century BCE; for further study, see Horace on Poetry: The Ars Poetica, C. O. Brink (Ed.) (Cambridge, UK: Cambridge University Press, 1971), passim. See K. Borinski, Die Antike in Poetik und Kunsttheorie von Ausgang des klassichen Altertums bis auf Goethe und Wilhelm von Humboldt (Leipzig: K. F. Koehler, 1914-1924), I, pp. 30, 97, 175, 183, and 238; II, p. 106, in particular, pp. 125-127, on the history of the dispute about ut pictura poesis; Mario Praz, Mnemosyne The Parallel Between Literature and the Visual Arts (Princeton: Princeton University Press, 1967), pp. 2-28; Mendelsohn, Paragoni: Benedetto Varchi Due Lezzioni, pp. 109-142, where Varchi notes in the third disputation, "Onde, se bene i poeti et i pittori imitano, non imitano però, ne le medesime cose, nei medesimi modi. Imitano quelli colle parole, e questi co' colori; il perché pare che sia tanta differenza fra la poesia e la pittura, quanta è fra l'anima e'l corpo. Bene è vero che, come i poeti discrivono ancora il di fuori, così i pittori mostrano quanto più possono il di dentro, cioè gli affetti.” See John R. Spencer (1957), “Ut Rhetorica Pictura: A Study in Quattrocento Theory of Painting," Journal of the Warburg and Courtauld Institutes, 20, pp. 26-44; Anthony Blunt, Artistic Theory in Italy (Oxford: Oxford University Press, 1968), p. 52; Rensselaer Lee, Ut Pictura Poesis: Humanist Theory of Painting (New York: W. W. Norton and Company, Inc., 1967), p. 1, n. 2; Dolce's Dialogo della Pittura (1557), M. Roskill (Trans.) (New York: New York University Press, 1968), pp. 97 and 239; and Gian Paolo Lomazzo's Trattato dell' arte della pittura, scultura et architettura (1584), which summarizes Leonardo's and Dolce's conceptions of the relationships between poetry and painting; and G. B. Armenini, De'veri precetti della pittura (1587), p. 23, who comments on this fashion: "Per cio si chiama la pittura, Poetica che tace, et la Poetica, Pittura che parla, et questa l'anima dover esser, et quella il corpo, dissimile pero quin questo si tengono, perche, l'una imita con i colori, l'altra con le parole. Ma certamente che qui quanto all' inventione predetta et quin quanto alla Verita sono d'una stessa proprietà et d'uno effetto medesimo.” Torquato Tasso refers as well to the poet as a pittore parlante (speaking painter) in Discorsi dell'arte poetica e del poema eroico (1587, new Italian edition Giovanni Gheradini and Angelo Fabroni (Eds.) [Charleston, SC: Nabu Press, 2012]). And in a letter to Vasari, Annibale Caro refers to the artist as a poet and painter: "L'inventione mi rimetto a voi, ricordandomi d'un altra somiglianza, che la poesia ha con la pittura, et di piú, che voi siete cosi poeta come pittore, et che ne l'una et ne l' altra con piu affettione et con piu studio s' esprimono i concetti et le idee sue proprie che d'altrui.” See Karl Frey (Ed.), Der literarische Nachlass Giorgio Vasaris (Munich: George Müller, 1923), I, p. 220. Letter 112 dated May 10, 1548.

${ }^{65}$ In associating Horace's concept of a poet with Vasari's artistic talent, I identify the poet to be a writer and poetry to be a written essay. In Vasari's case, his writing of the Vite and I Ragionamenti are examples of Horace's poetic notions. Horace: Epistles Book II and Arts Poetica, H. Rushton Fairclough (Trans.) (Cambridge, MA: Harvard University Press (Loeb Classical Library, No. 194), 1929 revised), Ars Poetica, lines 10-11: "Pictoribus atque poetis quidlibet audendi semper fuit aequa potestas" ("But painters and poets have always shared the right to dare anything"), and lines 38-39: "Sumite materiam uestris qui scributus, aequam uiribus et uerstate diu quid ferre recusant...” (“You who write choose a subject that's matched by your powers...”).
} 
Benché questo no dico per biasimare simili opinioni, perché ogni fatica aspetta premio, e potrà dire un poeta, io farò una finzione che significa cose gradi, questo medesimo farà il pittore, come fece Apelle la Calunnia; se voi diceste la poesia è più eterna, per questo dirò essere più eterne le opera d'un calderaio, ché 'l tempo più le conserva che le vostre e nostre opera; niente di meno è di poca fantasia; e la pittura si può, dipingendo sopra rame con colori di vetro, fare molto più eternale; noi per arte possiamo essere detti nipoti a Dio; se la poesia s'astende i filosofia morale, è questa i filosofia naturale, se quella descrive l'operazione della mete, questa considera quello che la mete opera ne movimenti: se quella spaventa I popoli colle infernali finzioni, questa colle medesime cose in atto fa il simile: poga si il poeta a figurare una bellezza, una fierezza, una cosa nefada e brutta, una mostruosa col pittore, faccia a suo modo come vuole trasmutazioni di forme, che il pittore no soddisfacci più, no s'è egli viste pitture avere tanta conformità colla cosa viva ch'ell'a ingannato homini e animali?

(And if a poet should say: "I will invent a fiction with a great purpose," the painter can do the same, as Apelles painted Calumny. If you were to say that poetry is more eternal, I say the works of a coppersmith are more eternal still, for time preserves them longer than your works or ours; nevertheless they have not much imagination. And a picture if painted on copper with enamel colors may be yet more permanent. We, by our arts may be called the grandsons of God. If poetry deals with moral philosophy, painting deals with natural philosophy. Poetry describes the action of the mind, painting considers what the mind may effect by the motions. If poetry can terrify people by hideous fictions, painting can do as much by depicting the same things in action. Supposing that a poet applies himself to represent beauty, ferocity, or a base, a foul or a monstrous thing, as against a painter, he may in his way bring forth a variety of forms; but will the painter not satisfy more? Are there no pictures to be see, so like the actual things, that they deceive men and animals?). ${ }^{66}$

In his Dialogue on Painting, Dolce expresses similar sentiments, characterizing the poet as a parlante dipintore, a speaking painter; the painter as a poeta mutolo, a mute poet. ${ }^{67}$ Years later, Vasari writes in $I$ Ragionamenti, "it is permissible for the brush to treat philosophical subjects as narrative, since poetry and painting, as sisters, use the same means."68

Vasari's conception of ut pictura poesis is related to artistic creativity as well as to his theory of painting. For Vasari, an artist's goal is to make two types of componimenti (compositions): componimenti d'arte (a visual arrangement of forms); and componimenti d'istorie (inventive story telling or history painting). ${ }^{69}$ A visual composition includes invezione (invention) and disegno. With invenzione, the artist's intellect conceives of an arrangement; with disegno, the artist's grasps an invenzione in a visual manner, thus manifesting a componimento.

\footnotetext{
${ }^{66}$ The Literary Works of Leonardo da Vinci (Scritti Letterari di Leonardo da Vinci cavati dagli autografi e pubblicati da), Jean Paul Rickter (Ed.) (London: Sampson Low, Marston, Searle \& Rivington, 1883), pp. 328-329, Notebooks 654-655.

${ }^{67}$ Dolce's Dialogo della Pittura (1557), Roskill (Trans.), pp. 97 and 239. Gian Paolo Lomazzo's Trattato dell' arte della pittura, scultura et architettura (1584) summarizes Leonardo's and Dolce's conceptions of the relationships between poetry and painting; see Lee, Ut Pictura Poesis, p. 1, n. 2. Cf. Giovanni Battista Armenini, De’veri precetti della pittura (1587), p. 23, see note 64. Cf. Karl Borinski, Die Antike in Poetik und Kunsttheorie vom Ausgang des klassichen Altertums bis auf Goethe und Wilhelm von Humboldt (Leipzig: K. F. Koehler, 1914-1924), I, pp. 30, 97, 175, 183, 238; II, pp. 106, 125-127, for the history of the dispute about ut pictura poesis.

${ }^{68}$ See Vasari-Milanesi, I Ragionamenti, VIII, p. 18: "E lecito al pennello trattare le cose della filosofia favoleggiando; atteso che la poesia e la pittura usano come sorelle i medesimi termini.” I Ragionamenti is not included in Bettarini-Barocchi.

69 See Bettarini-Barocchi, III, pp. 377 and 431. In this context, Vasari’s concept of history painting derives from Alberti’s concept of drama or istoria visualized in a work of part, particularly in painting. De Pictura and De Statua (1435 Latin versions): “And I may well stand looking at a picture ... with no less delight to my mind than if I was reading a good history; for both are painters, one painting with words and the other with the brush.” Vasari probably read the Latin versions, since the translation into Italian did not occur until 1547, about the same time that the Vite were in press. See Leon Battista Alberti, On Painting and on Sculpture: The Latin Texts of De Pictura and De statua, Cecil Grayson (Ed. and Trans.) (London: Phaidon, 1972), passim; Cecil Grayson (Ed.), La pittura: traduzione di Lodovico Domenichi (Venezia, 1547), facsimile (Bologna: Commissione per i testi di lingua, 1988); Alberti, On Painting, J. R. Spencer (Trans.) (New Haven: Yale University Press, 1996), pp. 56-57; Anthony Blunt, Artistic Theory in Italy: 1450-1600 (Oxford: Oxford University Press, 1962), pp. 68-102; and Svetlana Alpers (1960), Ekphrasis and Aesthetics Attitudes in Vasari's Lives,” Journal of the Warburg and Courtauld Institutes, 23, pp. 193-221.
} 
He further elaborates and considers in addition to invenzione two alternatives in a painter's development or achievement of artistic creativity: imitation (imitazione) and judgment (giudizio). ${ }^{70}$ Imitation is the copying of art as a method of learning, whereas invention is independent of imitation and constitutes the means for conceiving artistic ideas. Imitation serves to guide and teach the artist in composing and creating perfection. For Vasari, imitation draws from three sources: the first two are copying visual forms from nature or from a model (copia dal vero), ${ }^{71}$ and the third is imitating one's own work (imitare se stessi) ${ }^{72}$ He emphasizes that copying from nature is important for artists so that they may learn to create forms that are alive. ${ }^{73}$ It also helps artists learn how to draw in such a way that eventually they are capable of drawing anything from memory without needing a model. In the endpiece, the Fine Arts, although holding the instruments of their arts, are musing, and no model is visible. Vasari adds the intellectual faculty to imitation to the notion of giudizio (judgment). ${ }^{74}$

Questo disegno ha bisogno, quando cava l'invenzione d'una qualche cosa dal giudizio, che la mano sia mediante lo studio et essercizio di molti anni spedita et atta a disegnare et esprimere bene qualunche cosa ha la natura creato.

(Disegno requires, when it plucks the invention of something from the judgment, that the hand, through the study and practice of many years, quicken and act to design and express well anything that nature has created.) ${ }^{75}$

This is necessary when copying or selecting from nature, from one's work and from other masters in order to improve the artistic design. In doing so, artists' conceits are an improvement on nature, and so artists may claim that they surpassed nature. Thus, for Vasari, artists must study not only nature but also antiquity and other masters, so that they may learn how others acquire the experience of imitating nature. ${ }^{76}$ Vasari identifies examples of this achievement in the works of Leonardo, Michelangelo and Raphael, as indicated by the visual references in the endpiece's imagery, ${ }^{77}$ as well as in these artists' vite. For example, in reference to painting, Vasari compares Apelles and Zeuxis to Raphael, showing the Cinquecento master's superiority to the ancient masters:

\footnotetext{
${ }^{70}$ See Bettarini-Barocchi, Preface Two, III, pp. 3-5; Erwin Panofsky, Idea: A Concept in Art Theory (Columbia, SC: University of South Carolina Press, 1968), pp. 60-63; and Le Mollé, Vasari, pp. 99-152, for a discussion of invenzione, imitazione and maniera in the Vite.

${ }^{71}$ On Baldassare Peruzzi, see Bettarini-Barocchi, IV, p. 316 "si diede alla pittura con tanto studio che in brevissimo tempo fece in essa meraviglioso acquisto, imitando, oltre l'opere de' maestri migliori, le cose vive e naturali” “[He] applied himself to painting with such zeal, that in a very short time he made marvelous progress herein, imitating the works of the best masters as well as living and natural things”.

${ }^{72}$ See Bettarini-Barocchi, Preface to The Whole, I, p. 171: "Io so che l'arte nostra è tutta imitazione della natura principalmente” ("I know that our art is most of all on the imitation of nature"); Wolfram Prinz, "I ragionamenti del Vasari sullo sviluppo e declino delle arti,” in Il Vasari: Storiografo e Artista (Florence: Istituto di Studi sul Rinascimento, 1976), pp. 857-867; and Le Mollé, Vasari, pp. 117-126.

${ }^{73}$ Bettarini-Barocchi, Preface to the Whole, I, p. 20. Cf. Blunt, Artistic Theory in Italy, pp. 88-90.

74 See David Summers' comment on Vasari’s use of giudizio and disegno in Michelangelo and the Language of Art (Princeton, NJ: Princeton University Press, 1981), p. 370; and Robert Klein, “Judgment and Taste in Cinquecento Art Theory,” in Robert Klein, Form and Meaning: Essays on the Renaissance and Modern Art, Madeline Jay and Leon Wieseltier (Trans.); foreword by Henry Zerner (New York: Viking Press, 1979), pp. 161-169.

${ }^{75}$ See Bettarini-Barocchi, I, p. 111.

${ }^{76}$ On Michelangelo, see Bettarini-Barocchi, Preface Third, III, pp. 10-11: “Supera e vince non solamente tutti costo ch'hanno quasi che vinto già la natura, ma quelli famossisimi antichi, che solamente fuor d'ogni duppio la superarono" ("This master surpasses and excels not only all those artists who have well nigh surpassed nature herself, but even all the most famous masters of antiquity, who did, beyond all doubt, vanquish her most gloriously”); and LeMollé, Vasari, 142-146, on the imitation of the ancient masters.

${ }_{77}$ See Bettarini-Barocchi, IV, p. 31 on Leonardo; VI, pp. 155-156 on Raphael; and VI, pp. 3-4 on Michelangelo.
} 
Ma più di tutti il graziosissmo Raffaello da Urbino, il quale studiando le fatiche de' maestri vecchi e quelle de' moderni prese da tutti il meglio, e fattone raccolta, arricchì I'arte della pittura di quella intera perfezzione, che ebbero anticamente le figure d’Apelle e di Zeusi e più se si potesse dire o mostrare l'opere di quelli a questo paragone.

(The most graceful of all [painters] was Raphael of Urbino, who studied what had been achieved by both the ancient and the modern masters, selected the best qualities from all their works, and by this means so enhanced the art of painting that it equaled the faultless perfection of the figures painted in the ancient world by Apelles and Zeuxis, and might even be said to surpass them were it possible to compare his work with theirs.) ${ }^{78}$

In sculpture, Michelangelo surpassed the ancient sculptors, as Vasari writers in his Preface Third:

Ma quello che fra i morti e’vivi porta la palma e trascende e ricuopre tutti è il divino, Michelagnolo Buonarroti il qual non solo tiene il principato di una di queste arti ma di tutte tre insieme. Costui, supera e vince non solamente tutti costoro, ch'hanno quasi che vinto già la natura, ma quelli stessi famosi e simili antichi, che si lodatamente fuor' d'ogni dubbio la superarono, et unico si trionfa di quegli, di questi e di lei, non imaginandosi appena quella cosa alcuna sì strana e tanto difficile ch'egli con la virtù del divinissmo ingegno suo, mediante, l’industria, il disegno l'arte, il giudizio e la grazia di gran lunga non la trapassi: non solo nella pittura e ne' colori sotto il 1' qual genere si comprendono tutte le forme e tutti i corpi retti e non retti, palpabili et impalpabili, visibili e non visibili, ma nell'estrema rotondità ancora de' corpi, e con la punta del suo scarpello. E delle fatiche di così bella e fruttifera pianta son distesi già tanti rami e sì onorati, che l'aver pieno il mondo in si disusata foggia de' più saporiti frutti che siano, hanno ancora dato l'ultimo termine a queste tre nobilissime arti con tanta e sì meravigliosa perfezione, che ben si può dire e sicuramente le sue statue, in qualsivoglia parte di quelle, esser più belle assai che l'antiche conoscendosi nel mettere a paragone teste, mani, braccia e piedi formati dall'uno e dall'altro, rimanere in quelle di costui un certo fondamento più saldo, una grazia più interamente graziosa et una molto piú assoluta perfezione, condotta con una certa difficoltà, sì facile nella sua maniera, che egli è impossibile mai veder meglio.

(Michelangelo Buonarroti, who is supreme not in one art alone but in all three. He surpasses not only all those whose work can be said to be superior to nature but also the artists of the ancient world, whose superiority is beyond doubt.Michelangelo has triumphed over later artists, over the artists of the ancient world, over nature itself, which has produced nothing, however challenging or extraordinary, that his inspired genius, with its great powers of application, design, artistry, judgment, and grace, has not been able to surpass with ease.He has so enhanced the art of sculpture that we can say without fear of contradiction that his statues are in every aspect far superior to those of the ancient world.For if their work were put side by side, the heads, hands, arms, and feet carved by Michelangelo being compared with those made by the ancients, his would be seen to be fashioned on sounder principles and executed with more grace and perfection:the effortless intensity of his graceful style defies comparison.) ${ }^{79}$

In the endpiece, however, Vasari visualizes an abstract aspect of artistic creativity (ingegno). ${ }^{80}$ The Fine Arts are not depicted in the process of making an art form but, rather, they are shown cogitating. Their attire, portrayed barefooted and partially clothed, and their poses, head placement and glancing eyes allude to their lofty intellectual pursuit. Vasari depicts them symbolizing one type of creativity: invention. Sculpture, for example, has actualized her creation, as an object of invention is held in her hand, whereas Architecture and Painting are still conceiving in their mind their creation, as no object of art is visible. Architecture, for example, raises her head and is looking up for divine inspiration, while Painting, looking down in a state of pensiveness, is cogitating.

\footnotetext{
78 See Bettarini-Barocchi, Preface Three, IV, p. 8.

${ }^{79}$ See Bettarini-Barocchi, Preface Three, IV, pp. 10-12. See also Donatello’s vita, where Vasari writes, "Donato fece ritornare nel secolo nostro la scultura perfetta e meravigliosa come ne' tempi buoni degli antichi Greci e Romani” ("Donato returned in our century perfect and beautiful sculpture like in the best times of ancient Greece and Rome").

${ }^{80}$ See Bettarini-Barocchi, Preface Two, III, p. 62: "for creativity must be activated when the intellect wants to work, and when inspiration catches fire for then one sees excellent and divine results, and marvelous conceptions" ("l'ingegno vuole essere affaticato quando l'intelletto ha voglia di operare, e che il furor è accesso, perché allora si vede uscirne parti eccellenti e divini, e concetti meravigliosi”). Ingegno includes the faculty of cogitation.
} 
In the creation of the Fine Arts, Vasari incorporates his artistic theory, not only including the visual componimento but also expanding his artistic criteria in order to include an aesthetic judgment and refinement in the creation of the art form. He conceives of five attributes or properties, which he names $i$ cinque aggiunti ("the five additions"). These attributes of a visual componimento consist of regola, ordine, misura, disegno and maniera (rule, order, proportion, design and style) ${ }^{81}$ Thus, Vasari considers necessary for the creation of a good componimento the integration of these five properties according to their style. These five properties, however, are not necessarily applicable to all the arts of disegno as a unit or as a whole, although they may relate at times and in part to one or more area of the Fine Arts, with disegno being always their foundation.

Vasari defines these artistic characteristics in the Third Preface of the Vite. ${ }^{82}$

Ma perchè più chiaro ancor si conosca la qualità del miglioramento che ci hanno fatto i predetti artefici, non sarà certo fuori di proposito dichiarare, in poche parole, i cinque aggiunti che io nominai, e discorrer succintamente donde sia nato quelveri buono, che superato il secolo antico, fa il moderno sì glorioso. Fu adunque la regola nella architettura il modo del misurare delle anticaglie, osservando le piante degli edifici antichi nelle opere moderne, l'ordine fu il dividere l'un genere dall'altro, il che toccasse ad ogni corpo le membra sue, e non si cambiasse più tra loro il dorico, to ionico, il corinzio et il toscano; e la misura fu universale, et nella architettura, come nella scultura, fare i corpi delle figure retti, dritti e con le membra organizzate parimente; et il simile nella pittura. Il disegno fu lo imitare il più bello della natura in tutte, le figure, cosi scolpite come dipinte: la quale parte viene dallo aver la mano e l'ingegno che raporti tutto quello che vede l'occhio in sul piano, o disegno o in su fogli o tavola o altro piano, giustissimo et a punto; e così di rilievo nella scultura. La maniera venne poi la più bella, dall'aver messo in, uso il frequente ritrarre le cose più belle, e da quel più bello, o mani o teste $o$ corpi o gambe aggiungerle insieme e fare una figura di tutte quelle bellezze che più si poteva; e metterla, in uso in ogni opera per tutte le figure, che per questo si dice esser bella maniera. ${ }^{83}$

(But to the end that the nature of the improvement brought about by the aforesaid artists may be even more clearly understood, it will certainly not be out of place to explain in a few words the five additions that I have named, and to give a succinct account of the origin of that true excellence which, having surpassed the age of the ancients, makes the moderns so glorious. Rule, then, in architecture, was the process of taking measurements from antiquities and studying the ground plans of ancient edifices for the construction of modern buildings. Order was the separating of one style from another, so that each body should receive its proper members, with no more interchanging between Doric, Ionic, Corinthian, and Tuscan. Proportion was the universal law applying both to architecture and to sculpture, that all bodies should be made correct and true, with the members in proper harmony; and so, also, in painting. Drawing [disegno] was the imitation of the most beautiful parts of nature in all figures, whether in sculpture or in painting; and for this it is necessary to have a hand and a brain able to reproduce with absolute accuracy and precision, on a level surface — whether by drawing on paper, or

81 Bettarini-Barocchi, Preface Three, IV, p. 4. For Vasari, disegno means an overall composition, including invention (invenzione), color (colorito) and judgment (giudizio). See David Rosand, "Ekphrasis and the Renaissance of Painting: Observations on Alberti's Third Book," in Florilegium Columbianum: Essays in Honor of P. O. Kristeller (New York, 1987), pp. 147-166, in particular, pp. 153-154, on Alberti's "tripartite division of painting" as reflecting both the ancient rhetorical model and the actual practice of painting, and the evolution of these categories into mid-16th century program (invenzione, disegno and colorito).

82 Bettarini-Barocchi, Preface Two, III, p. 5, and Preface Three, IV, pp. 7-9. In the Third Preface of the Vite, Vasari makes clear that of the five elements or standards, three of them-misura, ordine and regola — relate in particular to the creation of disegno in architecture and derive from antiquity. However, his articulation of these three standards in relation to architecture indicates his familiarity with Leon Battista Alberti's writings on architecture, e.g., in Vasari's section on Architecture in Alle Tre Arti del Disengo: Architettura, Scultura e Pittura of the Vite, he notes: “Quanto sia grande l'utile che ne apporta l'architettura non accade a me raccontarlo, per trovarsi molti scrittori i quali diligentissimamente et a lungo n’hanno trattato ... già descritti da Vitruvio e dal nostro Leon Batista Alberti...” See Bettarini-Barocchi., I, p. 31. Alberti’s original Latin edition, De re aedificatoria, is first printed posthumously in Florence in 1485. Vasari's friend, Cosimo Bartoli, publishes his Italian translation in 1550 as L'architettura di Leonbatista Alberti, tradotta in lingua fiorentina da Cosimo Bartoli, gentil huomo e academico fiorentino. See also, Jane Andrews Aiken, “Leon Battista Alberti’s System of Human Proportions,” Journal of the Courtauld Institutes, 43 (1980), pp. 68-96.

${ }^{83}$ See Bettarini-Barocchi, Preface Three, IV, pp. 4-5. 
on panel, or on some other level surface-everything that the eye sees; and the same is true of relief in sculpture. Manner (style) then attained to the greatest beauty from the practice which arose of constantly copying the most beautiful objects, and jointing together these most beautiful things, hands, heads, bodies, and legs, so as to make a figure of the greatest possible beauty.This practice was carried out in every work for all figure for all the works executed is what is called beautiful manner [style]).

In clarifying and elaborating upon his artistic criteria for good (buon) componimenti, Vasari encourages a perfect rule for art (perfetta regola dell'arte), meaning excellence in overall visual composition (componimento visuale) and an inclusion of ethical subject in history painting (componimento d'istorie). In this manner, Vasari incorporates the creation of beauty in a work of art. His theory of art deals with the nature of the beautiful as it exists in art and nature as well as with the physicality and spirituality of beauty. Thus, unity between the visual and historical componimenti is visually exemplified in the portrayal of the Fine Arts in the endpiece.

For Vasari, the apprehension of a visual form in nature must arouse a sensation of beauty. The notion of beauty exists at two levels: physical and spiritual. The physicality of beauty is perceived in the painted image, and Vasari's spirituality of beauty is reflected in the evocation of the visual experience as indicated in the first dedication letter (1550) to Cosimo I de’ Medici, Duke of Tuscany, on the Vite:

Le sarà se non grata questa fatica presa da me di scrivere le vite, i lavori, le maniere e le condizioni di tutti quelli che, essendo già spente, l'hanno primieramente resuscitate, dipoi di tempo in tempo accresciute, ornate e condotte finalmente a quelle grado di bellezza e di maestà dove ella si trovano ai giorni d’oggi.

(I have thought that this labor which I have undertaken—of writing the lives, describing the works, and setting forth the various relations of those who, when art had become extinct, first revived, and then gradually conducted her to that degree of beauty and majesty wherein we now see her, would not be other than pleasing to your Excellency). ${ }^{84}$

Vasari connects beauty with disegno as he states in the Preface Three:

Il disegno fu lo imitare il più bello delta natura in tutte le figure, così scolpite come dipinte: la qual parte viene dallo aver la mano e l'ingegno che raporti tutto quello che vede l'occhio in sul piano, o disegni o in su fogli o tavola o altro piano, giustissimo et apunto; e così di rilievo nella scultura. La maniera venne poi la più bella, dall'avere messo in uso il frequente ritrarre le cose più belle, e da quel più bello, o mani o teste o corpi o gambe aggiungerle insieme e fare una figura di tutte quelle bellezze che più si poteva, e metterla, in uso in ogni opera per tutte le figure, che per questo si dice esser bella maniera.

(Disegno was the imitation of the most beautiful parts of nature in all figures, whether in sculpture or in painting; and for this it is necessary to have a hand and a brain able to reproduce with absolute accuracy and precision, on a level surface — whether by drawing on paper, or on panel, or on some other level surface — everything that the eye sees; and the same is true of relief in sculpture. Manner then attained to the greatest beauty from the practice which arose of constantly copying the most beautiful objects, and joining together these most beautiful things, hands, heads, bodies, and legs, so as to make a figure of the greatest possible beauty. This practice was carried out in every work for all figures, and for that reason it is called the beautiful manner). ${ }^{85}$

Vasari's creativity, in particular, his notions of beauty in art, depends on philosophical and poetical traditions of the sixteenth century. ${ }^{86}$ His humanistic sources of inspiration derive from his classical schooling

\footnotetext{
${ }^{84}$ See Bettarini-Barrocchi, Letter of 1550 to Cosimo I de’ Medici, Duke of Florence, I, p. 1.

${ }^{85}$ See Bettarini-Barocchi, Preface Three, IV, p. 4.

${ }^{86}$ See Lee, Ut Pictura Poesis, Introduction; C. W. Westfall, "Painting and the Liberal Arts: Alberti's View," Journal of the History of Ideas, 30 (1969), pp. 486-506; P. O. Kristeller, Renaissance Thought and the Arts (Princeton: Princeton University Press, 1965, 1980), passim; Paola Barocchi (Ed.), Generalia, Arti e Scienze, Le Arti (Turin: Einaudi, 1977), pp. 133-151, on Benedetto Varchi; and Mendelsohn, Paragoni, pp. 109-142.
} 
with Latinist Giovanni Pollastra (1465-1540) and the emblematist Pierio Valeriano (1477-1558), ${ }^{87}$ where he learns to integrate components of paganism with Christianity as well as understand emblematic symbolism in imagery. Furthermore, the courtly patronage of the Medici and Farnese families in Florence and Rome, respectively, provides him with access to the most renowned humanists of the time, such as Giovanni Battista Adriani (1513-1579), Cosimo Bartoli (1503-1572), Annibale Caro (1507-1566), Vincenzo Borghini (1515-1580) and Paolo Giovio (1483-1552). Vasari’s philosophical notions on art are combined with the Italian Renaissance restatement of Platonic and Neoplatonic aesthetics, in particular, Marsilio Ficino's Neoplatonic philosophy, where he integrates Platonic notions of beauty as well as Plotinus' concepts on proportions and symmetry in art. ${ }^{88}$

Some scholars of the Renaissance studying the intellectual and cultural transformations noted the impact of Ficino's Neoplatonism in the arts, in particular, in Florence, in the art of Botticelli, Filippino Lippi, Raphael and Michelangelo and, in Venice, in the art of Giorgione and Titian. ${ }^{89}$ These humanistic interpretations provided new insights into the study of Neoplatonism in other artists of the Cinquecento, namely Vasari. ${ }^{90}$

Vasari's notions about art depend on the philosophical and poetical tradition of Renaissance ${ }^{91}$ as well as on the Italian Renaissance restatement of Platonism by Marsilio Ficino. ${ }^{92}$ In Preface Three of the Vite, Vasari refers to beauty as symmetry and proportion of form and associates the beautiful with creativity and design

${ }^{87}$ See Robert W. Carden, The Life of Giorgio Vasari: A Study of the Later Renaissance in Italy (London: Philip Lee Warner, 1910), pp. 4 and 6.

${ }^{88}$ In 1492, Ficino translates and comments on Plotinus' Enneads. Original manuscript in the Biblioteca Medicea Luarenziana (Plut.82.10). See Kristeller, Renaissance Thought II, p. 92; Giuseppe Faggin, Plotino: Con Antologia Plotiniana (Rome: Asram Vidya, 1993), pp. 107-118: Enneads V 8-709, On Beauty Redemptions; and p. 232, referring to Plotinus, Enneads, I 6, 2, On Beauty: "Dunque l'idea, accostandosi, ordina, combinando insieme, le parti diverse di un essere, le reduce a un tutto armonionose e forma l'unità mediante il loro accordo, perchè essa è una e perchè l'essere da lei informato dev'essere uno, come puo esserlo un essere composte di parti. La bellezza dunque risiede in questo essere, una volta ridotto all'unità, e si dà le sue parti e all'insieme" ("Thus beauty, approaches, regulates, combines together, the different parts of a being [thing], [in doing so] it reduces them to a whole harmony and unity through their own accord because the form is one and because the form from its own formation, as the form can be composed of parts. Beauty, then, resides in this form, once reduced to unity, and its form is of parts and united together"). See also Riccardo Chairadonna, Plotino (Rome: Carocci, 2012), pp. 71-72; Laura Vestra "Love and Beauty in Ficino and Plotinus," in Konrad Eisenbichler and Olga Zorzi Pugliese (Eds.), Ficino and Renaissance Neoplatonism (Toronto: Dovehouse Editions, 1986), pp. 179-180; Patrizia Castelli, "I Segni e le Imagini," in Il Lume del Sole: Marsilo Ficino: Medico dell’Anima, ed. Patrizia Castelli (Florence: Opus Libri, 1985), pp. 11-23; and Sears R. Jayne (Ed. and Trans.), Marsilio Ficino: Commentary on Plato's Symposium on Love (Dallas, TX: Spring Publications, Inc., 1985), pp. 89-91.

${ }^{89}$ It is not the intention of this essay to discuss the Cinquecento historiography of Neoplatonism in the Arts, but the following sources are important in the study of Neoplatonism: N. Robb, Neoplatonism of the Italian Renaissance (New York: Octagon Books, Inc., 1968), passim; Chastel, Marsile Ficin et L’Art, passim; Eugenio Garin, “Images and Symbols in Marsilio Ficino,” in Portraits from the Quattrocento, Eugenio Garin (Ed.) (New York: Harper and Row Publishers, 1972), pp. 42-56; Ernest H. Gombrich, "Botticelli Mythologies," Journal of the Warburg and Courtauld Institutes, 8 (1945), pp. 7-60; Edgar Wind, Pagan Mysteries in the Renaissance (New York: W. W. Norton and Company, 1958), pp. 113-140; Erwin Panofsky, Studies in Iconology (New York: Harper and Row Publishers, 1965), pp. 171-230, on "Michelangelo and Neoplatonism," and pp. 129-169, on "Neoplatonism in Florence and North of Italy”; Kristeller, Renaissance Thought, pp. 44 and 65, on Raphael; Liana De Girolami Cheney, Botticelli's Mythological Images (Potomac, MD: Scripta Humanistica, 1985), passim; and Alessandra Mazzanti, "Filippino Lippi: un episodio particolare del Neoplatonism,” in Il Lude del Sole, Castelli (Ed.), pp. 135-148.

90 Sergius Kodera and Berthold Hub of Vienna International Conference on Iconology: Neoplatonism and Art in the Renaissance-Perspectives and Contexts of a (Controversial) Alliance, University of Vienna, 2011. See also Liana De Girolami Cheney and John Hendrix (Eds.), Neoplatonism in the Arts (New York: The Edwin Mellen Press, 2002); and Liana De Girolami Cheney and John Hendrix (Eds.), Neoplatonic Aesthetics: Music, Literature and the Visual Arts (London: Peter Lang, 2004).

91 Brink (Ed.), Horace on Poetry, Introduction; E. L. Hunt, "Plato and Aristotle on Rhetoric and Rhetoricians," Historical Studies of Rhetoric and Rhetoricians, R. F. Howes (Ed.) (New York: Cornell University Press, 1961), pp. 19-70; James Hutton (Ed. and Trans.), Aristotle's Poetics (New York: W. W. Norton \& Company, 1982), pp. 45-47, on the mimetic arts and imitation; and Paul Oskar Kristeller, “Renaissance Aristotelianism,” Greek, Roman, and Byzantine Studies 6 (1965), pp. 157-174.

${ }_{92}$ See Marsilio Ficino, Sopra lo amore: Ovvero Convito di Platone (De Amore), ed. and trans. Giuseppe Rensi (Milan: SE SRL, 2003), pp. 17-18 (hereafter Rensi, (Ed.), Ficino’s Sopra lo amore), a preface to Ficino’s Plato’s Symposium, where Ficino explains the aims of the oeuvre as well as his indebtedness to Plato. And in Chapter III, pp. 50-52, "Come l'amore e maestro di tutte le arti" ("How love is the teacher of all the arts"), Ficino further notes how the arts are connected with the Muses. 
(disegno) recalling the notion of proportions and beauty contained in a form. Ficino's concept of radiance or splendor, an element that results from the quality of unity inherent in the object, as expounded in Ficino's Commentary on Plato's Symposium about Love (Sopra lo Amore Ovvero Convito di Platone).

According to Vasari, the origin of beauty derives from God. He understands beauty to be a divine creation: "[God] fashioned the first forms of painting and sculpture in the sublime grace of created things," Creator of all things, from which perfectly and beautifully is born every perfection and beauty." "94 Ficino, too, claims that "God created Himself and He loves Himself, He loves His images and His Works." noting, "Come la bellezza di Dio partorisce lo amore” ("How God's beauty delivers love”), ${ }^{96}$ and that beauty is "a process of ascent from sensual cognition of earthly beauty to the apprehension of the immortal ideal of beauty itself." 97

Vasari also parallels Ficino's Neoplatonic notion of God as the creator of beauty with his own conception of beauty based on disegno. He writes that the formation of beauty needs order and proportion ("la bellezza [dipende] da ordine e proporzione"), ${ }^{98}$ and at times he also relates the concept of beauty with goodness ("bellezza e bontà"). ${ }^{99}$ Similarly, Ficino writes, "Che lo amore è beatissimo, perché egli è buono e bello" ("Love is magnificent because it is good and beautiful”). ${ }^{100}$ Hence, Vasari connects his ideas of beauty with Ficino's theory of beauty.Vasari further notes:

La maniera venne poi la più bella dall'avere messo in uso il frequente ritrattare le cose più belle, e da quel più bello, o mani o teste o corpi o gambe, aggiungerle insieme e fare una figura di tutte quelle bellezze che più si poteva, e metterla in uso in ogni opera per tutte le figure, che per questo si dice esser bella maniera.

(The style [manner] then attained to the greatest beauty from the practice which arose of constantly copying the most beautiful objects, and jointing together these most beautiful things, hands, heads, bodies, and legs, so as to make a figure of the greatest possible beauty.This practice was carried out in every work for all figures, and for that reason it is called the beautiful style [manner]). ${ }^{101}$

Erwin Panofsky views the Cinquecento tradition of connecting the principle of aesthetic perfection and beauty to the classical notion of symmetry "as a synthesis between the mystical spirit and the rational or between Neoplatonism and Aristotelianism." "102 In the compositional disegno of the endpiece, Vasari embraces Ficino's notion of the essence of beauty, an aesthetic quality that depends on measurability or proportions. This

\footnotetext{
93 See Bettarini-Barocchi, Preface To The Whole Work, I, p. 11.

${ }^{94}$ See Bettarini-Barocchi, III, p. 274.

95 See Michael J. B. Allen, Marsilio Ficino: Platonic Theology, vol. I (Cambridge, MA: Harvard University Press, 2001), Chapter XIII, p. 193, on how God loves and provides for His creation.

${ }^{96}$ See Rensi (Ed.), Ficino’s Sopra lo amore, pp. 30-31, commentary on the creation of beauty: "Come la bellezza di Dio partorisce lo amore" ("How God's beauty delivers love"). In this passage, Ficino states that he is citing Plato's Republic, Book IV.

97 See Rensi, ed., Ficino's Sopra lo amore, pp. 30-31, for Ficino's commentary on the creation of beauty and his citation of the passage on Plato's Republic, Book IV. See also Jayne, Marsilio Ficino, p. 90, and pp. 89-91, for Ficino's explanation on how Beauty is the splendor of the divine countenance; Chastel, "Le Beau: L'Universelle Volupte et la Lumiere," in Chastel, Marsile Ficin et L'Art, pp. 81-90; Vestra, "Love and Beauty in Ficino and Plotinus,” p. 185; and Liana De Girolami Cheney, Botticelli’s Neoplatonic Images (Potomac, MD: Scripta Humanistica, 1993), pp. 32-34.

98 See Bettarini-Barocchi, VI, p. 406, "Perchè le cose che non hanno fra loro ordine e proporzione non possono eziandio essere belle" ("Because things that lack between them order and proportion cannot beautiful").

99 See Bettarini-Barocchi, III, pp. 295 and 337, on beauty and goodness.

100 See Bettarini-Barocchi, III, p. 295; Rensi, ed., Ficino’s Sopra lo amore, p. 67, Chapter I, entitled "Che lo amore è beatissimo, perché egli è buono e bello" ("Love is magnificent because it is good and beautiful”).

101 See Bettarini-Barocchi, Preface Three, IV, p. 4.

102 See Erwin Panofsky, The Meaning of the Visual Art (Chicago: Chicago University Press, 1955), p. 89.
} 
is the ancient doctrine of the symmetrical and pleasant relationship of individual parts. ${ }^{103}$ In Ficino's Commentary on Plato's Symposium, in particular, the chapter on "Quante parti si richieggono a fare la cosa bella: è che la bellezza e dono spirituale" ("How may parts are required to create a beautiful form and how beauty is a spiritual gift"), he discusses how many things are required to create a beautiful body, such as arrangement (the distance between parts), proportion (quantity) and aspect (shape and color), for example, "the ears be in their place, [as well as] the eyes and nose, etc., and that the eyes be at equal distances near the nose ... proportion of the parts ... preserve the proper portion of the whole body."104 Thus, Vasari's theory of beauty derives jointly from the classical conception of physical beauty and from the Christian's credence of spiritual beauty, ${ }^{105}$ which are in turn integrated in Ficino's Renaissance Neoplatonic notion of spiritual beauty. ${ }^{106}$

Moreover, Vasari visualizes this notion of beauty as perfection in two of his classical history paintings (componimenti d' istorie) by selecting ancient themes where the artist composes a beautiful form through the process of selection and integration of parts: The Studio of Zeuxis of 1548, in his house at Arezzo (see Figure 11); and The Studio of Apelles of 1560, in his house in Florence (see Figure 12). ${ }^{107}$ For Vasari, the Neoplatonic spiritual beauty means the manifestation of vivacity, radiance and grace in the image perceived through reason and sight in order to move the human soul and delight the spirit, as depicted in his Saint Luke Painting the Virgin of 1562, in the Chapel of Saint Luke, in the Church of SS. Annunziata in Florence (see Figure 13). ${ }^{108}$

\footnotetext{
${ }^{103}$ See Jessica Moss, “Art and Ethical Perspective: Note on the Kalon in Plato’s Laws,” in Plato on Art and Beauty, A. E. Denham (Ed.) (New York: Palgrave, 2012), pp. 209-215, on aesthetic perspective and laws of proportion.

${ }^{104}$ See Rensi (Ed.), Ficino’s Sopra lo amore, pp. 78-79, Chapter VI, entitled “Quante parti si richieggono a fare la cosa bella: è che la belezza e dono spirituale" ("How many parts are required to create a beautiful form and how beauty is a spiritual gift"); and Jayne, Marsilio Ficino, pp. 93-95.

${ }^{105}$ Probably, Vasari's affinity with the Christian credo derives from his familiarity with Saint Thomas Aquinas's writing and Dominican patronage. The numerous paintings on Thomas Aquinas acquainted him in a special way with the Christian Fathers, e.g., Andrea Bonaiuto, The Triumph of Saint Thomas Aquinas of 1366, Cappellone degli Spagnoli, Santa Maria Novella, Florence; and Filippino Lippi, The Triumph of the Catholic Doctrine of 1489, Carafa Chapel, Santa Maria sopra Minerva in Rome.

${ }^{106}$ See Rensi (Ed.), Ficino’s Sopra lo amore, p. 67, Chapter III, entitled “Che la belleza è cosa spiritual” ("Beauty is a spiritual thing”).

107 See Liana De Girolami Cheney, “Vasari’s Depiction of Pliny’s Histories,” Explorations in Renaissance Culture, XV) (Ed.), (1989), pp. 97-120; and Fredrika Jacobs, “Vasari’s Vision of the History of Painting: Frescoes in the Casa Vasari, Florence,” Art Bulletin, 66 (1984), pp. 399-416.

${ }^{108}$ See Liana De Girolami Cheney, “Cappella degli Artisti: Montorsoli’s Marble Plaque,” in The Historian’s Eye: Essays $n$ Italian Art in Honor of Andrew Ladis, Hayden B. J. Maginnis and Shelley E. Zuraw (Eds.) (Athens, GA: Georgia Museum of Art, 2009), pp. 215-223; and Liana De Girolami Cheney, “Giorgio Vasari’s Theory of Feminine Beauty,” in Concepts of Beauty in Renaissance Art (London: Ashgate/Scolar Press, 1997), pp. 180-190.
} 


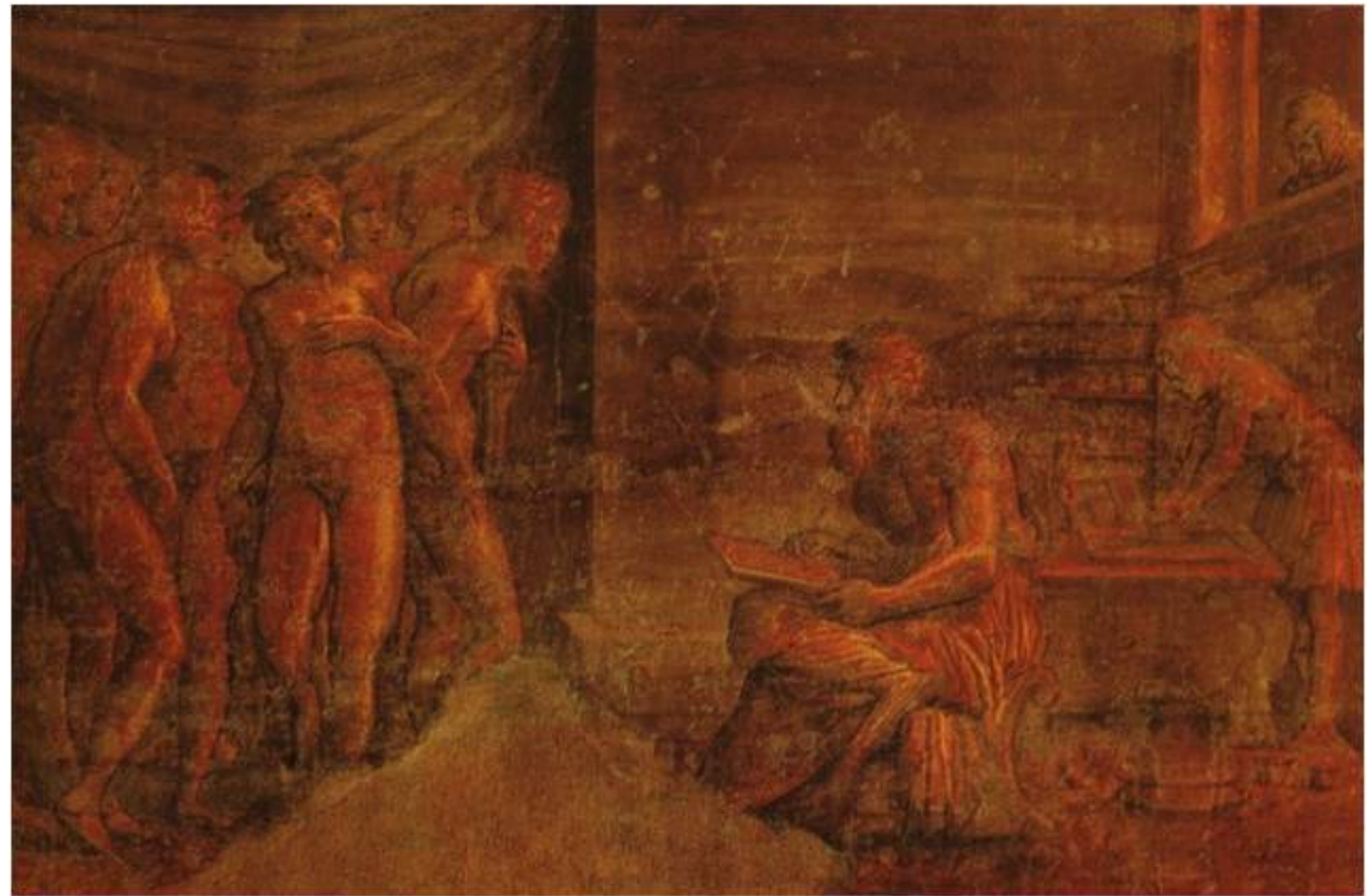

Figure 11. Giorgio Vasari, The Studio of Zeuxis, 1548, det. Chamber of Fortune, Casa Vasari, Arezzo. (Photo credit: Liana De Girolami Cheney)

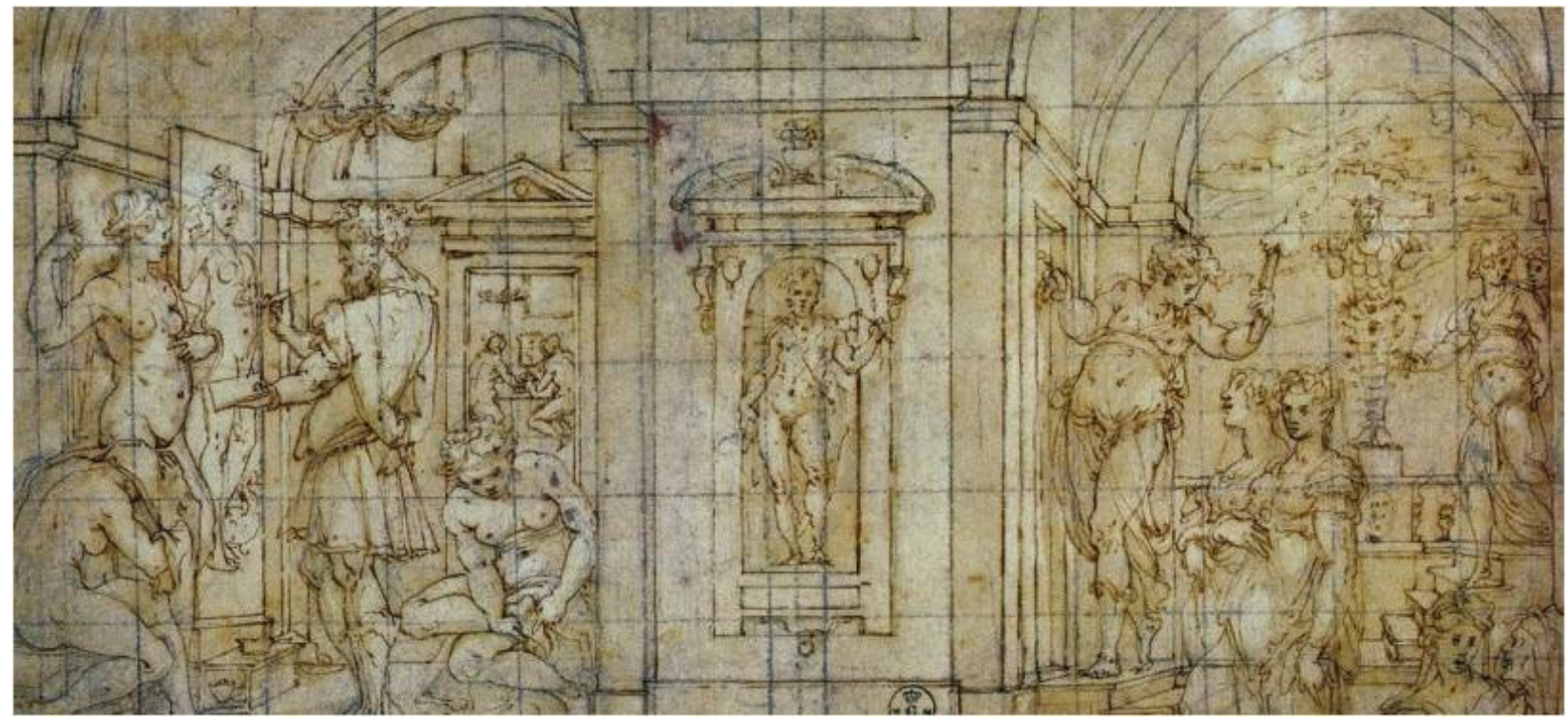

Figure 12. Giorgio Vasari, The Studio of Apelles, 1560. Drawing for the Sala of the Fine Arts, Casa Vasari, Florence. (Photo credit: Gabinetto Disegni e Stampe degli Uffizi, Florence (inv. n.1180E)) 


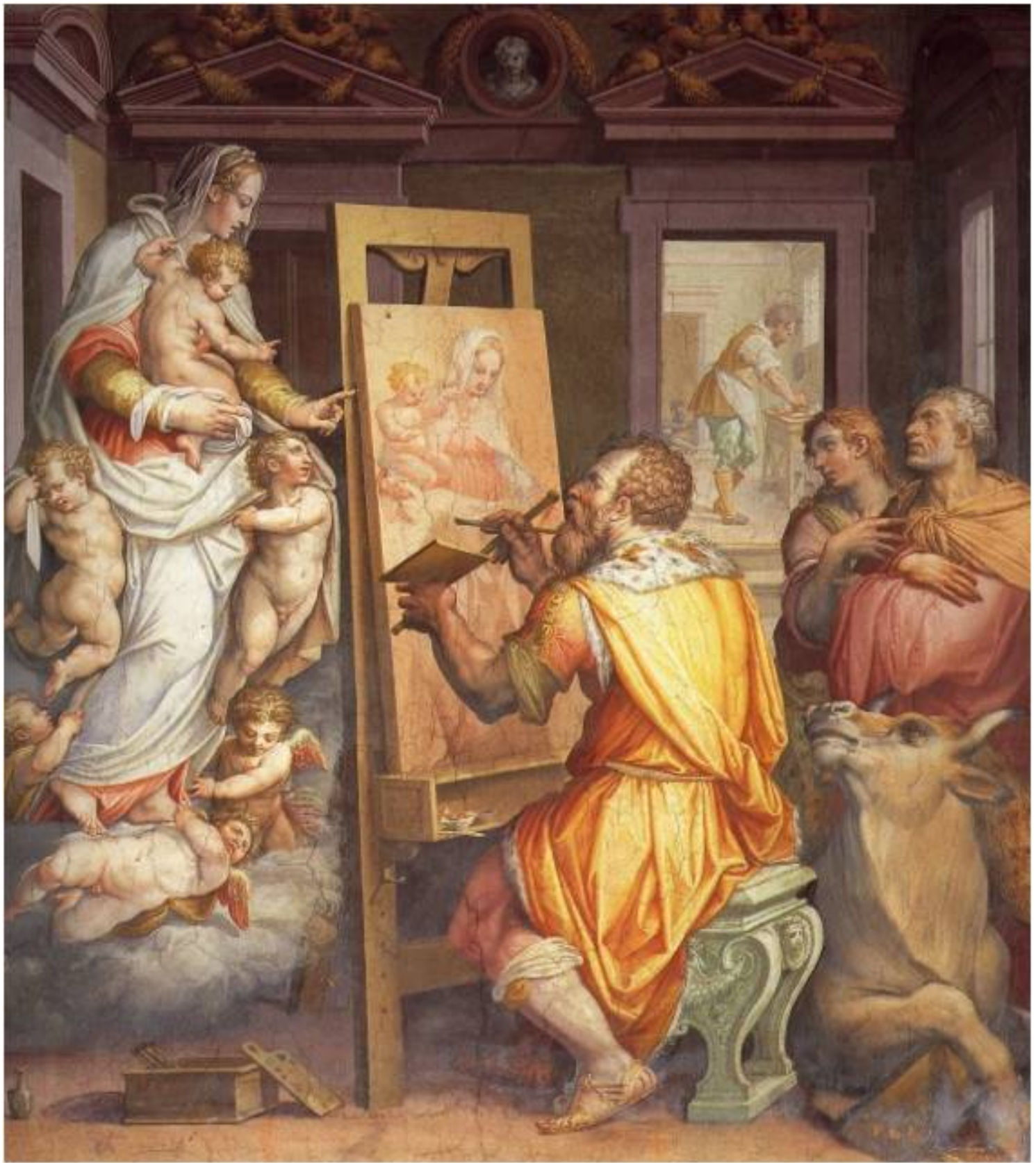

Figure 13. Giorgio Vasari, Saint Luke Painting the Virgin, 1562. Chapel of Saint Luke, in the Church of SS. Annunziata. Florence. (Photo credit: Liana De Girolami Cheney)

In accordance with the Neoplatonic theory of beauty, Vasari not only refers to beauty as symmetry and proportion of form but also associates the beautiful according to Ficino's concept of radiance or splendor, an element that emanates from the quality of unity inherent in the object. ${ }^{109}$ In his Commentary on Plato's Symposium about Love, Ficino relies on the ancient Greek philosopher's definition of beauty "as the splendor

\footnotetext{
109 See Reins (Ed.), Ficino’s Sopra lo amore, Chapter IV, p. 74, entitled “Che la belezza è lo splendore del volto di Dio” (“Beauty is the splendor of God").
} 
of divine goodness present everywhere, personal beauty expresses an interior moral goodness.”110

The notion of Neoplatonic splendor is a source of intellectual illumination, as is visualized in the endpiece: it emanates, at the top, from the celestial realm (Fame) to the intellectual realm of the Fine Arts, in the middle, and finally, it transforms and radiates into the natural realm (deceased artists). Metaphorically, the light awakens the souls of the deceased artists and lifts them into the realm of recognition, honor and fame. Displaying the new conception of art and the new role of artists, Vasari honors the virtue of Fame among the Fine Arts and recognized artists.

Vasari depicts several physical and metaphysical realms, employing the symbolism of illumination, mirroring and universality. In the endpiece, metaphorically, there are two types of lights: one is represented in the flaming torch, a natural light; and the second is depicted in the image of the sun and the sun's rays alluding to celestial or divine light. ${ }^{111}$ The emanation composed by the sun's rays is a transformation and reflection of the celestial realm that descends into the intellectual and the natural realms. The imagery of the emanation also alludes to a mirroring effect or reflecting light that is a celestial or an intellectual illumination. This type of illumination unites with the natural light in order to assist the faculties of seeing, perceiving and conceiving for the creation of a disegno.

Metaphorically, the mirror's reflection is a reference to artists' self-imaging, a physical and personal identification, as well as their artistic creations, a metaphysical signification of their world of beauty. The vicissitudes in their lives allude to the rotary movement, the Wheel of Fortune. But at the center of that rotation is the Cinquecento individual in Ptolemy's geocentric cosmology and Copernicus' heliocentric cosmology. ${ }^{112}$ The individual, in this case the artist, is an incarnation of microcosm in the macrocosmic world, as illustrated in the drawing of Leonardo's Vitruvius Man of 1500. The artists as the microcosm of the world absorb the magnitude of nature in their creations. The artists of the Vite incorporate in their artistic inventions the influences of past artists, who were also able to capture and appreciate the beauty of the natural world. The Cinquecento manifestation of the rotating movement of the earth around the sun is likened to a wheel in constant movement, an eternal return, similar to the artists' achievements that are immortalized through time. In the second edition of the Vite, Vasari surrounds the image of Fame and the Fine Arts with the motto, "Hac sospite nunquam hos perisee, Viros victos avt morte fatebor" ("While history lives, it would never be said, that artists’ work has perished”). ${ }^{113}$

\section{Conclusion}

Vasari's criteria of art and beauty consist of the study of nature, the capturing of nature through its imitation, and the surpassing of nature by improving on it. ${ }^{114}$ Thus, Vasari's ideals on beauty derive jointly

\footnotetext{
110 Jayne, Marsilio Ficino, p. 90. Ficino explains how Beauty is the splendor of the divine countenance, pp. 89-91. Ficino says about Plato: "I owe Plato much, to Cosimo no less. He realized for me the virtues of which Plato gave me the conception." See Harold Acton, The Pazzi Conspiracy: The Plot Against the Medici (London: Thames and Hudson, 1979), p. 12; Vestra, "Love and Beauty in Ficino and Plotinus,” p. 185; and Cheney, Botticelli’s Neoplatonic Image, pp. 32-34.

111 See Simone Bartolini, Sole e Simboli (Florence: Edizione Polistampa, 2013), pp. 47-51.

112 See Christopher Walker (Ed.), Astronomy before the Telescope (London: St. Martins Press, 1997), Introduction; and André Goddu, Copernicus and the Aristotelian Tradition: Education, Reading, and Philosophy in Copernicus' Path of Heliocentrism (Leiden: Knoniklijke Brill, 2010), pp. 245-246, discussing the manuscript of 1514, where he expounds his theory on the earth rotating around the sun.

113 Vasari is citing a Virgilian motto from Aeneid (Book VIII, II: 470-477). See Rubin, Giorgio Vasari, p. 222, for an explanation on how Vincenzo Borghini suggested this motto to Vasari.

114 See Bettarini-Barocchi, Preface Three, IV, pp. 10-12.
} 
from the classical conception of physical beauty and from the Neoplatonic notion of spiritual beauty. That is to say, for Vasari, the classical concept of beauty means a creation of a beautiful image from the combination of parts of the body commensurately and proportionately arranged as a whole, as represented in the disegno of the endpiece, where the Fine Arts are holding artistic instruments for demonstrating their creativity. For Vasari, the Neoplatonic spiritual beauty means the manifestation of vivacity, radiance and grace in the image, which is conceived through the mind (intellect) and the visual perception (sight). This aesthetic visualization moves the soul and delights the spirit, as indicated in the conceit of the endpiece of the Fine Arts. ${ }^{115}$ Thus, in this disegno, Vasari honors the artists for creating beauty, ascending them into intellectual and celestial realms.

Disegno is the imitation of the most beautiful parts of nature in all figures, whether in sculpture or in painting; and for this it is necessary to have a hand and a brain able to reproduce with absolute accuracy and precision. (Giorgio Vasari, Preface III, Vite)

\section{References}

Acton, H. (1979). The Pazzi conspiracy: The plot against the Medici. London: Thames and Hudson.

Alberti, L. B. (1996). On painting. (J. R. Spencer, Trans.). New Haven: Yale University Press.

Alciato, A. (1531/1546/1546/1549/1551). Emblemata. Augsburg: Heinrich Steyner; Lyons: Macé Bonhomme for Guillaume Rouille; Venice: Aldus Manutius.

Alexander, J. (Ed.). (1968). Jerusalem Bible. New York: Doubleday \& Company.

Allen, M. J. B. (1981). Marsilio Ficino and the Phaedran Charioteer. Los Angeles, CA: University of California Press.

Allen, M. J. B. (1984). The Platonism of Marsilio Ficino. Los Angeles, CA: University of California Press.

Allen, M. J. B. (2001). Marsilio Ficino: Platonic theology. Cambridge, MA: Harvard University Press.

Alpers, S. (1960). "Ekphrasis” and aesthetics attitudes in Vasari’s Lives. Journal of the Warburg and Courtauld Institutes, 23, 193-221.

Armstrong, A. H. (Trans.). (1984). Plotinus, Enneads (5 Vols.). Cambridge, MA: Harvard University Press.

Barocchi, P. (Ed.). (1977). Generalia, Arti e Scienze, Le Arti (Generalities on art and science: The arts). Turin: Einaudi.

Barocchi, P. (Ed.). (1979). Scritti d'Arte del Cinquecento: Disegno VIII (Writings on sixteenth century art: Drawing VIII). Turin: Giulio Einaudi.

Bartolini, S. (2013). Sole e Simboli (The sun and symbols). Florence: Edizione Polistampa.

Bettarini, R., \& Barocchi, P. (1971-1986). Giorgio Vasari, Le vite de’ piú eccellenti architetti, pittori, et scultori edizione 1550 (Giorgio Vasari, the lives of the most excellent architects, painters and sculptors, 1550 edition). Florence: Sansoni.

Bjurström, P. (2001). Italian drawings from the collection of Giorgio Vasari. Stockholm: Nationalmuseum.

Blunt, A. (1962/1968). Artistic theory in Italy: 1450-1600. Oxford: Oxford University Press.

Boas, B. (Trans.). (1950). The hieroglyphics of Horapollo. New York: Bolligen Series, XXIII.

Boase, T. S. R. (1971). Giorgio Vasari: The man and the book. Princeton: Princeton University Press.

Brink, C. O. (Ed.). (1971). Horace on poetry: The Ars Poetica. Cambridge, UK: Cambridge University Press.

Buchanan-Brown, J. (Trans.). (1994). Jean Chevalier and Alain Gheerbrant. A dictionary of symbols. Oxford: Basil Blackwell, Ltd.

Caciorgna, M., \& Guerrini, R. (2004). Il pavimento del duomo di Siena (The pavement of the Cathedral of Siena). Siena: Silvana Editoriale.

Carden, R. W. (1910). The life of Giorgio Vasari: A study of the later Renaissance in Italy. London: Philip Lee Warner.

Cartari, V. (1556). Imagini delli Dei degl'Antichi (Images of the ancient gods). Venice: Evangelista Deuchino \& Gio. Batttista Pulciani.

Castelli, P. (1985). I Segni e le Imagini (Signs and images). In P. Castelli (Ed.), Il Lume del Sole: Marsilo Ficino: Medico dell'Anima (Sun's light: Marsilio Ficino: Doctor of the soul) (pp. 11-23). Florence: Opus Libri.

Castiglione, B. (1967). The book of the courtier. Baltimore, MD: Penguin Books.

115 See Panofsky, Idea: A Concept in Art Theory, pp. 129-141. Other examples of Vasari's visualization of beauty are the Toilette of Venus of 1555-1558, in Staatsgalerie, Stuttgart; and Saint Luke Painting the Virgin of 1562, in the Chapel of the Artists, SS. Annunziata in Florence. 
Cecchi, A. (2011). Giorgio Vasari: Disegnatore e Pittore (Giorgio Vasari: Draughstman and painter). In A. Cecchi, A. Baroni, and L. Fornasari, Giorgio Vasari, disegnatore e pittore: "studio, diligenza et amorevole fatica." (Giorgio Vasari: draughtsman and painter: Study, diligence and loving efforts) (pp. 11-23). Milan: SKIRA.

Chairadonna, R. (2012). Plotino (Plotinus). Rome: Carocci.

Chastel, A. (1975). Marsile Ficin et L'Art (Marsilio Ficino and art). Geneva: Droz.

Cheney, L. D. (1985). Botticelli’s mythological images. Potomac, MD: Scripta Humanistica.

Cheney, L. D. (1989). Vasari's depiction of Pliny's histories. Explorations in Renaissance Culture, XV, 97-120.

Cheney, L. D. (1994). Vasari's pictorial musing on the Muses: The Chamber of Apollo of the Casa Vasari. Studies in Iconography, 15 (Spring), 135-177.

Cheney, L. D. (1995). Giorgio Vasari’s Sala dei Cento Giorni: A Farnese celebration (Giorgio Vasari's hall of the one hundred: A Farnese celebration). Exploration in Renaissance Culture, XXI, 121-151.

Cheney, L. D. (1997). Giorgio Vasari's theory of feminine beauty. In Concepts of beauty in Renaissance art (pp. 180-190). London: Ashgate/Scolar Press.

Cheney, L. D. (2002 reprint). Giorgio Vasari’s Calliope, Muse of poetry and music. In L. De Girolami Cheney and J. Hendrix (Eds.), Neoplatonism and the arts. New York/London: Edwin Mellen Press.

Cheney, L. D. (2004). Giorgio Vasari’s Studio, Diligenza ed Amorevole Fatica (Giorgio Vasari’s Study, Diligence and Loving Efforts). In A. Barriualt, et al. (Eds.), Reading Vasari (pp. 259-277). London: Philip Wilson.

Cheney, L. D. (2006). The homes of Giorgio Vasari. London: Peter Lang Publishing.

Cheney, L. D. (2009). Cappella degli Artisti: Montorsoli’s Marble Plaque (The chapel of the artists: Montorsoli's Marble Plaque). In H. B. J. Maginnis and S. E. Zuraw (Eds.), The Historian's eye: Essays in Italian art in honor of Andrew Ladis (pp. 215-223). Athens, GA: Georgia Museum of Art.

Cheney, L. D. (2012). Giorgio Vasari’s fine arts: Neoplatonic visualization of invention, imitation and beauty. In L. Marquez (Ed.), Figura. Studi sull'immagine nella tradizione classica (Figure. Studies about the images in the classical tradition). Retrieved from http://figura.art.br/revista

Cheney, L. D. (2016). Giorgio Vasari and mannerist architecture: A marriage of beauty and function in urban spaces. Journal of Literature and Art Studies, 6 (10), 1150-1171.

Cheney, L. D. (October 2012). Giorgio Vasari’s Prefaces: Art and theory. London: Peter Lang Publishing.

Cheney, L. D., \& Hendrix, J. (Eds.). (2002). Neoplatonism in the arts. New York: The Edwin Mellen Press.

Cheney, L. D., \& Hendrix, J. (Eds.). (2004). Neoplatonic aesthetics: Music, literature and the visual arts. London: Peter Lang.

Chevalier, J., \& Gheerbrant, A. (1994). A dictionary of symbols. (J. Buchanan-Brown, Trans.). Oxford: Basil Blackwell, Ltd.

Chiaradonna, R. (2012). Plotino (Plotinus). Rome: Carocci.

Collobi-Ragghianti, L. (1974). Il Libro de’ Disegni del Vasari (Vasari’s book of drawings) (2 Vols.). Florence: Vallecchi.

Colonna, F. (1499). Hypnerotomachia Poliphili. Venice: Aldus.

D’Ancona, P. (1902). Le rappresentazioni allegoriche delle arti liberali (On the allegorical representations of the liberal arts). L'Arte, 13, 137, 221-227, 269-289, 370-385.

de Castris, P. L. (2001). Polidoro Da Caravaggio. Naples: Electa.

de Tervarent, G. (1977). Attributs et Symboles dans L'Art Profane (Attributes and symbolism in profane art). Geneva: Droz.

Degenhart, B., \& Schmitt A. (1969). Methoden Vasaris bei der Gestaltung seines Libro (Vasari's methodology in the formation of his book on drawings). Studien zur toskanischen Kunst. Festschrift für L. H. Heydenreich (Studies on Tuscan art. Collection in honor of L. H. Heydenreich). Munich: Georg Müller, pp. 645-656.

del Vita, A. (1938). Lo Zibaldone di Giorgio Vasari (Giorgio Vasari’s miscellany). Rome: R. Istituto Archeologico e Storia dell'Arte.

Ebeling, F. (2007). The secret history of Hermes Trismegistus: Hermeticism from ancient to modern times. New York: Cornell University Press.

Faggin, G. (1993). Plotino: Con Antologia Plotiniana (Plotinus: With an anthology on Plotinus’ writings). Rome: Asram Vidya.

Fenichel Pitkin, H. (1984). Fortune is a woman: Gender and politics in the thought of Niccolò Machiavelli. Chicago: University of Chicago Press.

Ficino, M. (1996). Meditations on the soul: Selected letters of Marsilio Ficino. (C. Salaman, Ed. \& Trans.). Rochester, VT: Inner Traditions International.

Ficino, M. (2003). Sopra lo amore: Ovvero Convito di Platone (De Amore) (On Love: About Plato’s Symposium). (G. Rensi, Ed. \& Trans.). Milan: SE SRL. 
Frey, K. (Ed.). (1923). Der literarische Nachlass Giorgio Vasaris (The correspondence of Giorgio Vasari). Munich: George Müller.

Garin, E. (1972). Images and symbols in Marsilio Ficino. In E. Garin (Ed.), Portraits from the Quattrocento. New York: Harper and Row Publishers.

Gibbons, F. (1968). Dosso and Battista Dossi. Princeton: Princeton University Press.

Goddu, A. (2010). Copernicus and the Aristotelian tradition: Education, reading, and philosophy in Copernicus' Path of Heliocentrism. Leiden: Knoniklijke Brill.

Gombrich, E. H. (1945). Botticelli mythologies. Journal of the Warburg and Courtauld Institutes, 8, 7-60.

Gombrich, E. H. (1957). A classical topos in the introduction to Alberti’s Della pittura. Journal of the Warburg and Courtauld Institutes, 20, 170-179.

Halliwell, S. (1988). Plato Republic 10. Warminster: Aris and Phillips.

Halliwell, S. (2012). Beyond the mirror of nature: Plato's ethics of visual forms. In A. E. Denham, Plato on art and beauty (pp. 173-205). New York: Palgrave McMillan.

Hesiod. (1976). Theogony. (D. Wender, Trans.). Baltimore: Penguin Books.

Hunt, El. L. (1961). Plato and Aristotle on rhetoric and rhetoricians. In R. F. Howes (Ed.), Historical studies of rhetoric and rhetoricians (pp. 19-70). New York: Cornell University Press.

Jacobs, F. (1984). Vasari’s vision of the history of painting: Frescoes in the Casa Vasari, Florence. Art Bulletin, 66, 399-416.

Jayne, S. R. (1952). Ficino and the Platonism of the English Renaissance. Comparative Literature, 4 (Summer), 214-238.

Jayne, S. R. (Ed. \& Trans.). (1985). Marsilio Ficino: Commentary on Plato’s symposium on love. Dallas, TX: Spring Publications, Inc.

Jowett, B. (1980). The collected works of Plato. Princeton: Princeton University Press.

King James Bible (KJV). (2006). Cambridge, UK: Cambridge University Press as Cambridge Bibles in Baker Publishing Group.

Klein, R. (1979). Form and meaning: Essays on the Renaissance and modern art. (M. Jay \& L. Wieseltier, Trans.; Foreword by H. Zerner). New York: Viking Press.

Kodera, S., \& Berthold, H. (2011). Vienna international conference on iconology: Neoplatonism and art in the Renaissance-perspectives and contexts of a (controversial) Alliance. Vienna: University of Vienna.

Kristeller, P. O. (1961). Renaissance thought: The classic, scholastic and humanist strain. New York: Harper \& Brothers.

Kristeller, P. O. (1965a). Renaissance Aristotelianism. Greek, Roman, and Byzantine Studies, 6, 157-174.

Kristeller, P. O. (1965b). Renaissance thought and the arts. Princeton: Princeton University Press.

Kristeller, P. O. (1965c). Renaissance thought II. New York: Harper and Row Publishers.

Kristeller, P. O. (1980). Renaissance thought and the arts. Princeton: Princeton University Press.

Kristeller, P. O. (Ed.). (1985). The letters of Marsilio Ficino (3 Vols.). New York: Ginko Press.

Le Mollé, R. (1988). Georges Vasari: et le vocabulaire de la critique d'art dans les "Vite” (Giorgio Vasari and the vocabulary of the theory of art in the Lives). Grenoble: Ellug.

Lee, R. (1967). Ut Pictura Poesis: Humanist theory of painting. New York: W. W. Norton and Company, Inc.

Leon, B. A. (1972). On painting and on sculpture. In C. Grayson (Ed. \& Trans.), The Latin texts of De Pictura and De statua. London: Phaidon.

Leslie Thomson, L. (2000). Classical Origins. In Fortune: “All is but fortune” (pp. 11-20). Washington, DC: University of Washington Press.

Maclehose, L. S. (Trans.). (1960). Vasari on technique. G. B. Brown, (Ed.). New York: Dover Publications, Inc.

Mandelboum, A. (Trans. \& Ed.). (1995). Dante, Divine Comedy, Il Paradiso. New York: Knopf Doubleday.

Milanesi, G. (Ed.). (1970-1994). Giorgio Vasari. Le vite de’ piú eccellenti Pittori, Scultori, et Architettori (The lives of the most excellent painters, sculptors and architects). Florence: G. C. Sansoni.

Moore, T. (1990). The planets within. Hudson, NY: Lindisfarne Press.

Moss, J. (2012). Art and ethical perspective: Note on the Kalon in Plato's Laws. In A. E. Denham (Ed.), Plato on art and beauty (pp. 209-215). New York: Palgrave.

Panichi, R. (1991). La Tecnica dell'arte negli scritti di Giorgio Vasari (The techniques of art in the writings of Giorgio Vasari). Florence: Alinea.

Panofsky, E. (1955). The meaning of the visual art. Chicago: Chicago University Press.

Panofsky, E. (1965). Studies in iconology. New York: Harper and Row Publishers.

Panofsky, E. (1968). Idea: A concept in art theory. Columbia, SC: University of South Carolina Press. 
Praz, M. (1941/1947/1964). Studies in seventeenth century imagery (2 Vols.). London/Rome: Phaidon.

Praz, M. (1967). Mnemosyne the parallel between literature and the visual arts. Princeton: Princeton University Press.

Reau, L. (1955-1959). Iconographie del 'Art Chrétien (Christian iconography). Paris: Presses universitaries de France.

Rickter, J. P. (Ed.). (1883). The literary works of Leonardo da Vinci. London: Sampson Low, Marston, Searle \& Rivington.

Ripa, C. (1970). Iconologia. E. Mandowsky, (Ed.). New York: George Olms Verlag.

Robb, N. (1968). Neoplatonism of the Italian Renaissance. New York: Octagon Books, Inc.

Rorty, R. (1979). Philosophy and the mirror of nature. Princeton: Princeton University Press.

Roskill, M. (Trans). (1968). Dolce’s Dialogo della Pittura (Dialogue on painting) (1557). New York: New York University Press.

Rubin, P. (1955). Giorgio Vasari: Art and history. London: Yale University Press.

Rushton Fairclough, H. (Trans.). (1929). Horace: Epistles book ii and arts Poetica, Cambridge, MA: Harvard University Press.

Russell, D. (1981). Alciati’s emblems in Renaissance France. Renaissance Quarterly, XXXIV, 540-55.

Seznec, J. (1961). The survival of the pagan gods. New York: Harper and Row Publishers.

Spencer, J. R (1957). Ut Rhetorica Pictura: A study in quattrocento theory of painting. Journal of the Warburg and Courtauld Institutes, 20, 26-44.

Summers, D. (1981). Michelangelo and the language of art. Princeton, NJ: Princeton University Press.

The letters of Marsilio Ficino. (1975-1978). Preface by Paul Oskar Kristeller, Translated and Edited from Latin by members of the Language Department of the School of Economic Science in London (no names) (3 Vols.). New York: Gingko Press.

van Marle, R. (1932). Iconografie de l'art profane au moyen-âge et a la Renaissance (Iconography of profane art from the Middle Ages to the Renaissance). Hague: Martinus Nijhoff.

Vasari, G. (1550). Le vite de' piú eccellenti architetti, pittori, et scultori italiani, da Cimabue insino a' tempi nostri nell'edizione per I tipi di Lorenzo Torrentino Firenze (The lives of the most excellent Italian architects, painters and sculptors from Cimabue including our on time represented in the editions for the press of Lorenzo Torrentino of Florence).

Vestra, L. (1986). Love and beauty in Ficino and Plotinus. In K. Eisenbichler and O. Z. Pugliese (Eds.), Ficino and Renaissance Neoplatonism (pp. 179-180). Toronto: Dovehouse Editions.

von Schlosser, J. (1886). Giustos Fresken in Padua und die Vorläufer der Stanza della Segnatura (Giusto’s frescoes in Padua and the precursors of the Signature Room). Jahrbuch der kunsthistorischen Sammlungen des allerhöchsten Kaiserhauses, 17, 13-100.

Walde, Ch. (1996-2000). Die Musen (The Muses). In H. Cancik and H. Schneider (Eds.), Der Neue Pauly (The New Pauly, modern encyclopedia of ancient art). Stuttgart: J. B. Metzler.

Walker, C. (Ed.). (1977). Astronomy before the telescope. London: St. Martins Press.

Walker, P. D. (2000). Spiritual and demonic magic: From Ficino to Campanella. University Park, PA: The Pennsylvania State University Press.

Westfall, C. W. (1969). Painting and the liberal arts: Alberti’s view. Journal of the History of Ideas, 30, 486-506.

Wind, E. (1958). Pagan mysteries in the Renaissance. New York: W. W. Norton and Company. 